\title{
CAN THE NEW DEAL'S THREE R'S BE REHABILITATED? A PROGRAM-BY-PROGRAM, COUNTY-BY-COUNTY ANALYSIS
}

\author{
Price V. Fishback \\ Shawn Kantor \\ John Joseph Wallis \\ Working Paper 8903 \\ http://www.nber.org/papers/w8903 \\ NATIONAL BUREAU OF ECONOMIC RESEARCH \\ 1050 Massachusetts Avenue \\ Cambridge, MA 02138 \\ April 2002
}

The authors are deeply indebted to Larry Neal and Joseph Mason who facilitated the collection of the New Deal data used in the paper. Financial support has been provided by National Science Foundation Grants SBR-9708098 and SES-0080324, the Earhart Foundation, the University of Arizona Foundation, and the University of Arizona Office of the Vice President for Research. The views expressed herein are those of the authors and not necessarily those of the National Bureau of Economic Research.

(C) 2002 by Price V. Fishback, Shawn Kantor and John Joseph Wallis. All rights reserved. Short sections of text, not to exceed two paragraphs, may be quoted without explicit permission provided that full credit, including $\mathbb{C}$ notice, is given to the source. 
Can the New Deal's Three R's Be Rehabilitated?

A Program-by-Program, County-by-County Analysis

Price V. Fishback, Shawn Kantor and John Joseph Wallis

NBER Working Paper No. 8903

April 2002

JEL No. D78, E62, H50, N42

\begin{abstract}
We examine the importance of Roosevelt's "relief, recovery, and reform" motives to the distribution of New Deal funds across over 3,000 U.S. counties, program by program. The major relief programs most closely followed Roosevelt's three R's. Other programs were tilted more in favor of areas with higher incomes. For all programs spending for political advantage in upcoming elections was a significant factor. Roosevelt's successful reelections were based on developing specific programs for a broad range of constituents, delivering on his stated goals, but also spending more at the margin for political purposes.
\end{abstract}

Price V. Fishback

Department of Economics University of Arizona

Tucson, AZ 85721

and NBER

pfishback@bpa.arizona.edu
Shawn Kantor

Department of Economics University of Arizona

Tucson, AZ 85721

and NBER

skantor@u.arizona.edu
John Joseph Wallis

Department of Economics

University of Maryland

College Park, MD 20742

and NBER

wallis@econ.umd.edu 


\section{Can the New Deal's Three Rs Be Rehabilitated? A Program-by-Program, County-by-County Analysis}

In the consistent development of our previous efforts toward the saving and safeguarding of our national life, I have continued to recognize three related steps ... Relief was and continues to be our first consideration. It

calls for large expenditures and will continue in modified form to do so for a long time to come. . The second step was recovery, and it is sufficient for me to ask each and every one of you to compare the situation in agriculture and in industry today with what it was fifteen months ago. At the same time we have recognized the necessity of reform and reconstruction. ...

President Franklin D. Roosevelt (1934)

\section{Introduction}

During the New Deal the federal government distributed unprecedented amounts of grants and loans to state and local governments, leading to the federal government's share of GNP to rise from about 4 to 9 percent during the 1930s (Wallis and Oates, 1998, p. 157). Economic historians and public choice scholars have long acknowledged the wide variation in the federal government's per capita spending and lending across the United States and have devoted significant research to understanding the determinants of this relatively uneven distribution. ${ }^{1}$ Over the past three decades a number of scholars have used econometric analysis to test whether New Deal administrators followed Roosevelt's high-minded public goals of "relief, recovery, and reform" or whether they used federal spending and patronage to achieve their political goals of maintaining support for Roosevelt and building a lasting Democratic political coalition. 
To date, research on New Deal spending provides only partial support for the notion that the New Deal was designed to promote relief, recovery, and reform. Regression coefficients on the relief and recovery variables - drop in income from 1929 to 1933, unemployment, and the number of relief cases have the expected sign two-thirds of the time, but in half of those cases the null hypothesis of no effect cannot be rejected. Most tests find very little evidence of any reform aspect of the New Deal. We revisit the determinants of New Deal expenditures in this paper by examining the distribution of funds in a comprehensive and disaggregated fashion, focusing program-by-program across over 3,000 U.S. counties. $^{2}$

To better understand what motivated New Deal administrators, it is important to focus on the individual programs because each was designed to address specific and varied problems. Politicians typically do not publicize their largesse by discussing government spending in general terms; instead, they boast of the programs that address specific problems and benefit specific constituencies. For example, when President Roosevelt was asked what his administration was doing for the unemployed, he pointed to the Federal Emergency Relief Administration (FERA), Civil Works Administration (CWA), and the Works Progress Administration (WPA), agencies that put the unemployed back to work and provided relief for the destitute. Roosevelt responded to the depression in farming with the Agricultural Adjustment Administration (AAA), the Farm Credit Administration (FCA), and the Farm Security Administration (FSA), and each had its own subsets of programs. Given this programmatic emphasis, it would be inappropriate to expect the major relief programs, for instance, to have been responsive to agricultural needs. ${ }^{3}$ Focusing our attention on individual programs allows more precision in understanding how the New Deal dealt with distinctly different policy problems in relief, agriculture, public works, and public loan programs. Table 1 shows the amount of spending or lending in each of the New Deal programs we consider in this paper.

Refocusing the analysis of New Deal spending from the state level to the county level is equally important. First, the New Deal programs involved multiple layers of political administration. The ultimate success of each program was determined as much by what happened within states as it was by 
what happened across states. Second, there is ample documentation in the New Deal qualitative literature that state politicians sometimes viewed the New Deal much differently from the federal government. Some actively sought New Deal funds in various programs, while governors in Oklahoma, Virginia, North Carolina, and others seemed to disdain the New Deal. ${ }^{4}$ Only Wallis (1984, 1987, and 1998), Couch and Shughart (1998), Fleck (1999b, 1999c, 2001a), and Strömberg (2001) have tried to control for

the impact of state and local government decision-making on federal spending explicitly. ${ }^{5}$ We are able to control for the attitudes of state governments explicitly in our county-level analysis by including state dummy variables that account for state attitudes that were common to all counties within each state.

A third reason the county-level data can be superior to the state data lies in the adage "all politics is local." Whether the monetary benefits of the New Deal reached their local communities would have ultimately determined voters' assessments of the economic and political effectiveness of the New Deal. Had the Roosevelt administration simply sought to use the New Deal for re-election purposes, voters would have had to witness the spending locally, not simply at the federal or state levels. ${ }^{6}$ County-level data, therefore, affords more precise testing of the determinants of New Deal spending.

\section{Measures of the Three Rs in Prior Research}

Historians hold a variety of opinions of the nature of the New Deal. Schlesinger (1958), Degler (1959), and Freidel (1973) argue that the New Deal moved as far as possible toward social reforms given the climate of the Great Depression. In the 1960s a revisionist view developed as Leuchtenburg (1963), Zinn (1966), Conkin (1967), and Bernstein (1968) argued that the New Deal was basically conservative. ${ }^{7}$ There was certainly plenty of controversy during the 1930s: New Deal critics charged the Roosevelt administration with using the distribution of funds to enhance its own political power. These charges received substantial press in late 1938 as newspaper columnists ridiculed WPA administrator Harry Hopkins for allegedly declaring to friends that "we shall tax and tax and spend and spend and elect and elect" (McJimsey, 1987, p. 124). Yet the general impressions of the detailed, non-econometric studies of Key (1937), Brown (1940), Howard (1943), E. A. Williams (1968), J. K. Williams (1968), and Patterson 
(1969) were that political opportunism was not a primary motivating factor in the distribution of New Deal funds.

Economic historians began examining the distribution of funds with a statistical approach when Arrington (1969) noted the substantial disparities in New Deal funding across states. Reading (1973), attempting to empirically test the importance of the relief, recovery, and reform motives, treated relief and recovery as a combined category and his proxies for reform might better be described as measuring income redistribution. His econometric results suggested that aggregate New Deal grant funds were distributed to promote relief and recovery, but not reform (see Table 2). Wright (1974) developed a political-economic model of the Electoral College and then tested the importance of presidential politics in an econometric horse race by adding a series of factors to measure how the New Deal funds might have been used to enhance Roosevelt's re-election prospects. He found that politics dominated New Deal spending decisions and the three Rs had a statistically negligible role

Table 2 shows how relief, recovery, and reform (or income redistribution) measures perform in the large number of econometric studies of the distribution of New Deal funds. The many blank cells in the table suggest that scholars have used a variety of specifications. Had the New Deal been reformminded and redistributive, we would expect negative relationships between New Deal spending and income per capita, manufacturing wages, median education, and farm values. We would expect positive relationships between New Deal spending and the percentage of tenants among farmers and percent black. Had the New Deal focused on relief and recovery, we would expect a negative relationship between New Deal spending and the growth in income from 1929 to 1933 and positive relationships between unemployment rates and relief cases per capita.

Most of the studies summarized in the top part of the table have focused on a 48-state crosssection of aggregate New Deal spending on non-repayable grants from 1933 to 1939, although Wallis (1984, 1987, and 1998) and Couch and Shughart (1998) have used a panel of annual data. The bottom section of the table shows the results of a series of studies on specific programs, most using state-level data. Only Fleck (1999b, 2001a) and Stromberg (2001) have used a national county-level data set, 
although missing data for some of the control variables in each of those studies cause the loss of at least 400 (probably rural) counties. Fleck (1999c) also looked at the distribution of FERA spending in southern counties and Couch and Williams (1998) and Couch, Atkinson, and Wells (1998) have looked at the distribution of New Deal funds and agricultural funds across counties within Alabama.

Of all the potential tests for reform listed in the table, only three are unequivocally consistent with the hypothesis that the New Deal had a reform component. Fleck (2001b) found that aggregate New Deal spending might have been negatively related to income per capita and Fleck (1999b, 2001a) found that relatively more relief jobs in 1937 and 1940 were distributed in lower wage areas. Of 21 tests of the hypothesis that the New Deal was designed to offset the severe income drop from 1929 to 1933, 19 found coefficients consistent with this idea, but in only half of those cases was the hypothesis of no effect rejected. Of 31 tests of the hypothesis that the New Deal was used to offset unemployment problems, 24 have the appropriate sign, but only 18 reject the hypothesis of no effect and in two cases the coefficient of the lagged effect is the wrong sign. Our sense of these results, taken as a whole, is that the record of the New Deal with respect to relief and recovery is mixed and that it had very little to do with reform. Table 2 shows how the econometric literature on the determinants of New Deal spending has evolved, as most papers have contributed by adding new variables to the analysis. Yet a closer look at the table shows that nearly all of the papers suffer from the omission of at least one key variable category. Wright (1974) added presidential politics to Reading's (1973) analysis. Once Anderson and Tollison (1991) mentioned the importance of Congress, nearly all scholars writing later have included some measure of congressional activity. Only Wallis (1984, 1987, and 1998), Couch and Shughart (1998; but only for the WPA), Fleck (1999b, 1999c, and 2001a), and Stromberg (2001) have sought to control for the important role that state governments played in determining the distribution of New Deal funds. Our primary goals in this paper are to extend the econometric New Deal literature in two directions: to move the level of analysis from the state level to the county level and to examine the major New Deal programs individually. 


\section{An Intuitive Model of New Deal Spending}

Consider a simplified portrayal of the problem faced by the federal administrators of a generic New Deal program, like a relief program. Congress, in consultation with the president, established a budget to provide grants to state and local governments to help them provide relief. The law contained very loose guidelines about how the monies were to be distributed. Roosevelt maintained in speeches that the administration's goal was to provide relief where it was needed. Spending money where people were most needy enhanced the president's re-election chances because constituents reward political responsiveness. On the other hand, political power can be fleeting; at the margin, the administrator confronted pressure to shift spending to swing states or to reward voters who defected from the Republicans in 1932. The administrator also faced pressures from congressmen who wanted their own constituents to benefit from federal largesse. Congressional influence had to be considered because Congress provided the funding for the program, wrote the funding formulas, and had broad oversight power over the New Deal administrator's activities. Special attention had to be paid to the demands of the members of key committees that directly determined the fate of the program. Further complicating our hypothetical administrator's job, many New Deal programs involved significant interaction with state and local politicians who faced their own set of political objectives and constraints. State and local governments were directly involved in the New Deal allocation process as they sometimes had to provide matching funds for grants. Moreover, they proposed projects for federal funding and ultimately selected those individuals who would receive the relief locally. Thus, an aggressive state and local government would have been able to extract more New Deal funding, all else equal.

The scenario above focuses on the administration of a single program. Developing a theoretical model that incorporates all of these various pressures across multiple programs with contradictory goals is daunting. ${ }^{8}$ We simplify the problem by considering the president, as head of the executive branch, as the maximizing agent, making choices over the entire range of programs, subject to constraints imposed by Congress, state and local governments, voters, and interest groups. The president's multivariate maximization problem was, in fact, a series of choices over each individual program. The exogenous 
variables in the president's decision-making included all of the factors over which he and the executive branch had no direct control, including the state of the economy, the pressures exerted by various interest groups, the limits imposed by congressional rules and oversight, and the attitudes of state governments. Since the president and his staff paid attention to all of the factors in administering the different programs, all of the exogenous factors should be included in the analysis of each of the individual programs. At the margin, each program was a substitute for another since a dollar more for unemployment relief, for example, meant a dollar less for agriculture. As a result, every exogenous variable belongs in the reduced form specification of each program. ${ }^{9}$

\section{The Estimation Equations}

Previous scholars have typically estimated reduced-form equations with per capita New Deal spending (aggregated across programs) regressed on variables designed to capture the relief, recovery, and reform motives, presidential reelection strategies, congressional clout, and other variables that describe the economic structure of the geographic areas. Following this literature we start with the following basic equation:

$$
\mathrm{ND}_{\mathrm{ij}}=\alpha_{0}+\operatorname{Pop}_{\mathrm{ij}}\left(\beta_{0}+\sum_{\mathrm{k}=1}^{\mathrm{n}} \beta_{\mathrm{k}} \mathrm{X}_{\mathrm{ijk}}+\sum_{\mathrm{j}=1}^{48} \beta_{\mathrm{j}} \mathrm{b}_{\mathrm{j}}+\varepsilon_{\mathrm{ij}}\right)
$$

where $\mathrm{ND}_{\mathrm{ij}}$ is total New Deal spending in county i from 1933 through 1939 (to keep the notation simpler, we suppress an index for programs). Pop $\mathrm{i}_{\mathrm{ij}}$ is the population in 1930 in county $\mathrm{i}$, state $\mathrm{j}, \mathrm{X}_{\mathrm{ijk}}$ represents $\mathrm{k}$ different exogenous explanatory variables $X_{k}$ indexed by county $i$ and state $j$, and $b_{j}$ represent state dummy variables. The term $\varepsilon_{\mathrm{ij}}$ is a stochastic error with mean zero and variance $\sigma^{2}$.

Wallis (1998) suggested that the federal government structured total New Deal spending such that each geographic area received a base amount of spending, plus a base amount of spending per person, plus additional spending per person based on economic, political, reform, recovery, or relief motives. ${ }^{10}$ He argued that political decision-makers would have found it politically unpalatable to spend nothing in a state or county, so he structured his model so that each geographic unit was assumed to have received 
some base amount ( $\alpha_{0}$ in equation (1) above). Our equation assumes that the remainder of New Deal spending was distributed on a per capita basis. Each county is assumed to have received a base amount, $\beta_{0}$, per person, in addition to per capita amounts, $\beta_{\mathrm{k}}$, based on the exogenous characteristics of the county. We also allow for differences in spending per person across each state.

The equation we estimate is determined by dividing equation (1) by population, creating per capita New Deal spending equation similar to the ones previously estimated in the literature:

$$
\operatorname{PCND}_{\mathrm{ij}}=\alpha_{0} \frac{1}{\operatorname{Pop}_{\mathrm{ij}}}+\beta_{0}+\sum_{\mathrm{k}=1}^{\mathrm{n}} \beta_{\mathrm{k}} \mathrm{X}_{\mathrm{ijk}}+\sum_{\mathrm{j}=1}^{48} \beta_{\mathrm{j}} \mathrm{b}_{\mathrm{j}}+\varepsilon_{\mathrm{ij}}
$$

where PCND $_{\mathrm{ij}}$ is per capita New Deal spending in county $\mathrm{i}$, state $\mathrm{j}$. The $\alpha_{0}$ coefficient shows the baseline total spending on the program in all counties in the United States. The $\beta_{0}$ coefficient is the baseline spending associated with each person across all counties. Finally, the $\beta_{\mathrm{j}}$ coefficients represent the amounts of per capita spending unique to state $\mathrm{j}$, relative to Connecticut (the excluded state). Since the specification is in per capita terms, heteroskedasticity should not be an issue.

Table 3 lists the explanatory variables and their summary statistics. The variables follow those used in the existing literature, with some additional variables designed to capture issues that have not been fully addressed. The variables are sorted according to the hypotheses being tested and we provide a sketch of how to interpret the signs of the coefficients.

One of the central features of many of the New Deal spending and loan programs was that state and local governments had a significant impact on the extent of federal New Deal spending locally. Some programs, such as the WPA, the non-federal portions of the PWA, FERA, and the Social Security Administration, had distinct matching features, although it is not clear how tightly federal administrators adhered to these requirements. ${ }^{11}$ Even if matching was not an explicit feature of a program, many of the spending programs were determined by the types of projects proposed and the applications filed by state and local governments. Thus, their willingness to expend the time and resources necessary to make the application, as well as to make sure that the application was of high quality, was an important determinant of whether or not the federal government expended funds. There is ample documentation that different 
states had vastly different attitudes toward the New Deal (Patterson 1967, Braemen, Bremner and Brody 1975, Abrams 1992, Collins 1992). To capture the different states' attitudes toward the New Deal, which were common to all counties within the state, we include a series of state dummy variables. These state dummy variables also control for other factors, particularly the nature of Senate representation. Wallis (1987 and 1998) points out that omission of such controls for the difference in state attitudes can lead to omitted variables problems that can cause the coefficients to be biased.

The variables measuring the support for Democratic presidential candidates and voter turnout in presidential elections help to control for differences in attitudes toward the New Deal at the county level. Roosevelt supporters might have been more willing to press for New Deal involvement locally. Finally, general political savvy and political activity can be measured by the percentage of adults casting presidential votes in 1932. This variable captures voting by both parties, so it might better be treated as a measure of political activism and interest in the political process generally. This in turn could lead to greater pressure for New Deal funds.

There is one final econometric point worth noting. We have sought to avoid problems of simultaneity bias by using economic variables from 1929 and 1930, before the New Deal was established. The one variable where there could be a small problem with endogeneity is our measure of the growth rate in real per capita retail sales between 1929 and 1933. The 1933 value might be affected to some degree by some of the New Deal spending that occurred in the second half of 1933 . However, since the vast majority of the spending for nearly every program came after 1933, we do not see this as a serious problem. $^{12}$

\section{Regression Results}

Based on the coefficients from the regression equations, we have calculated elasticities for each New Deal program with respect to each variable. Appendix Tables 1 through 5 report all of the regression coefficients and t-statistics. The elasticities represent the percentage change in per capita funds associated with a one-percent increase in the respective variable's sample mean, holding all others 
constant. Asterisks denote the elasticities where the coefficient in the original regression was found to be statistically significantly different from zero in a two-tailed t-test at the 10 percent level. The elasticities for the relief, recovery, and reform variables are reported in Table 5, for the presidential variables in Table 6, and for the structural economic variables in Table 7.

\section{V.1 Relief and Recovery}

Economists analyzing the distribution of New Deal funds originally sought to test whether the

Roosevelt administration's actions followed the relief, recovery, and reform mantra. ${ }^{13}$ In this sub-section we focus on the relief and recovery hypothesis. Had the New Deal sought to promote relief and recovery of the depressed economy, we would expect more spending where unemployment in 1930 was higher and where the percentage of farm acreage with crop failures in 1929 was greater. We expect a negative relationship between the change in economic activity from 1929 to 1933 (as measured here by retail sales per capita) and New Deal spending.

The centerpieces of the Roosevelt administration's efforts to promote relief and recovery were the Federal Emergency Relief Administration (FERA) from 1933 through 1935, the Civil Works Administration (CWA) in the winter of 1933-34, the Works Progress Administration (WPA) from 1935 through 1939, and the public assistance programs developed under the Social Security Act of 1935 (SSAPA). ${ }^{14}$ These programs distributed 62.7 percent of the non-repayable New Deal grants (see Table 1). The regression results indicate that each of the relief programs responded to economic hardships. Each program shows a positive and statistically significant relationship between the allocation of funds and the unemployment rate in 1930. The elasticities are 0.252 for the WPA, 0.105 for the FERA, 0.078 for the SSAPA programs, and 0.047 for the CWA. Similarly, for each program there is a negative relationship with the difference in log retail sales per capita from 1929 to 1933 . The FERA elasticity is largest in magnitude at -0.238 , followed by -0.068 for the CWA, while the negative effects are much smaller in size and not statistically significant for the WPA and SSAPA programs. Our findings generally reconfirm those of other studies summarized in Table 2 that suggest that the relief and recovery motives were important determinants of the allocation of New Deal spending. 
An alternative avenue for the federal government to provide work for the unemployed and to stimulate a depressed economy were the public works programs, including the Public Works Administration (PWA) established in 1933, the Public Roads Administration (PRA) which built on prior federal highway programs, and the Public Buildings Administration (PBA). The PWA was originally established as part of the program to provide relief for the unemployed, but its chief administrator Harold Ickes focused on large-scale public works projects designed to have a lasting impact on the economy. This emphasis led to relatively long delays in the start of construction and, thus, in the hiring of the unemployed. In contrast, Harry Hopkins, the administrator of the FERA, CWA, and WPA, focused his attention on putting the unemployed back to work as quickly as possible. In the famous "Battle for Relief," Hopkins won the lion's share of the funding for his projects and the PWA's focus shifted away from unemployment relief toward the building of lasting infrastructure (Schlesinger, 1958, pp. 283-96). It is not clear that Ickes sought to promote recovery in the regions where the economy declined most. $\mathrm{He}$ saw the PWA as stimulating the overall economy and not specific regional economies. In congressional hearings Ickes was asked whether the PWA focused on variations in unemployment when distributing projects to various areas. Ickes replied: "In a general way, we have that in the back of our heads. But if the purpose of this program is to give employment, to relieve unemployment, and to stimulate heavy industries, it does not matter a great deal whether you are building in California or New York" (quoted in J. K. Williams, 1968, p. 116 n.22). ${ }^{15}$

Total PWA activity combined two programs. Federal PWA programs were sponsored by federal agencies with strong central control over those programs. Non-federal PWA grants and loans were made to state and local governments. The impetus for these programs came from state and local governments.

Despite the professed limited attention paid to the unemployed, the PWA federal program appears to have been highly responsive to the unemployment rate in 1930. The unemployment elasticity for the federal PWA was the highest of any program studied at 0.693 . The effect for PWA spending as a whole, however, was muted because the non-federal PWA grants were negatively related to the unemployment ratio in 1930 with an elasticity of -0.122 . The regression results are also consistent with Ickes's relative 
indifference to recovery efforts in the hardest hit areas. The elasticity for the federal PWA program with respect to changes in log retail sales of 0.99 suggests that the federal program spent more funds in the areas that experienced the least damaging declines from 1929 to 1933. In sum, the PWA agency was a study in contrasts with respect to promoting relief and recovery.

The agencies least interested in relief and recovery were the PRA and PBA. The PRA was statutorily locked into a formula based on population and land size and Fleck (2001b) found that on a per capita basis state-level PRA spending was very highly correlated with land area (0.994). Our countylevel analysis suggests that the PRA and the PBA largely ignored recovery and relief and may have even exacerbated cross-county economic differences. Both programs had a negative and statistically significant relationship with the unemployment ratio and a positive relationship with the growth in retail sales. In other words, the better an economy fared during the Depression, the more money it received for federal roads and buildings.

Farm programs were designed to promote higher incomes for farmers. We have data on the Agricultural Adjustment Administration's (AAA) payments to farmers to take acreage out of production, the Farm Credit Administration's (FCA) loans to farmers through the Land Bank Commissioner for crop loans and for debt relief, the Farm Security Administration's (FSA) mixture of loans and grants to financially troubled farmers, and the Rural Electrification Administration's (REA) loans to bring electricity to farms. Many of the farm programs display a negative and statistically significant relationship to the unemployment rate, although measured unemployment may have been more of an urban phenomenon during the period. All farm programs except the REA distributed funds to areas where the downturns were steepest as measured by the growth rate of retail sales from 1929 to 1933 . The strongest negative elasticities of -0.392 and -0.223 were found for the FSA's grant and loan programs, respectively. This is not surprising; the FSA was specifically charged with aiding farmers in financial distress. The basic FSA programs were started under the relief-oriented FERA and the focus on relief apparently continued after the FSA was established. The FSA programs also distributed more funds where there was a higher rate of farm failures in 1929, although the elasticities are relatively low. The 
AAA payments and the FCA payments were also negatively related to the downturn from 1929 to 1933 , but had small negative correlations with the rate of farm failures in 1929.

The final group of programs provided loans or insured mortgage loans. The largest of these was the Reconstruction Finance Corporation (RFC), which started under the Hoover administration, and loaned money to banks, industry, local governments, and provided funding for a variety of New Deal programs. The Home Owners' Loan Corporation (HOLC) provided direct lending to homeowners who were already at risk of defaulting on their own mortgages. The HOLC loaned money at more favorable terms for these at-risk borrowers. Finally, the Federal Housing Administration (FHA) insured private lenders against the default risk associated with making home improvement and mortgage loans.

The only loan and insurance program that appears related to relief and recovery is the HOLC, which had an elasticity of -0.059 for the growth rate of retail sales. The coefficients in the RFC analysis might well be biased in a positive direction with respect to the retail sales variable because increased RFC lending in 1932 might have softened the downturn in many areas. In general, the loan programs were ones where the borrowers sought funding from the federal government and the rules of the lending program required that the agencies pay attention to the ability of their borrowers to repay the loans. Roosevelt and other administrators viewed repayment pragmatically. They worried about a series of loan defaults in the early stages of the New Deal that would have led to a public outcry, thus inhibiting their future ability to continue the programs or add new programs. The results from the analysis suggest that the emphasis on likely repayment of the loans largely offset any desire to loan more in counties with higher unemployment or where the economic downturn was deeper. The HOLC was focused on providing assistance to troubled mortgagees, but even it was careful to lend in cases where the chances of repayment were relatively higher. Had there been no focus on repayment, the elasticity with respect to the growth rate in retail sales would have been even more negative. 


\section{V.2 Reform and Redistribution}

The New Deal push for reform had a variety of meanings, including the introduction of federal social insurance, changes in the organization of labor markets, and many legislative mandates that were national in scope and likely unrelated to the geographic distribution of New Deal funds. Following previous scholars we have included several variables in the analysis to assess the extent to which the New Deal was redistributive. If reform and redistribution were important factors in the allocation of New Deal funds, we would expect a negative relationship between New Deal spending and measures of a county's income level, which we proxy using retail sales per capita in 1929. County-level personal income data do not exist, but retail sales per capita is a reasonable alternative because the state-level correlation between the two variables (income and retail sales) was 0.86 in 1929. We expect a positive relationship between New Deal spending and the black percentage of the population and the percent illiterate in 1930, as both groups tend to be in the lower tier of the income distribution, holding constant the mean level of income. Had the farm programs been redistributive, we expect a negative relationship between average farm size and spending on the farm programs. Finally, we include a measure of the upper tail of the income distribution - the ratio of tax returns in 1929 to population in 1930 - within each county. Income tax rates were common to the entire U.S. and less than 7 percent of households earned enough income to pay income taxes. ${ }^{16}$ If the New Deal were redistributive, the tax return ratio should be inversely related to New Deal spending.

The studies that focus on aggregate New Deal spending have found almost no evidence that the New Deal was redistributive. This result may be a phenomenon of the aggregation across programs or across counties within states. By contrast, our analysis of the individual relief programs shows strong signs of a redistributive bent. Three of the four major relief programs have a negative and statistically significant relationship with per capita retail sales, with elasticities ranging from -0.135 for the FERA to 0.205 for the WPA. The CWA has a small negative elasticity that is statistically insignificant. All four also display negative relationships with the tax return ratio, although the elasticities are statistically significant for only the WPA and the Social Security programs. If we expand the discussion of relief to 
include the Farm Security Administration's relief programs, we find the anticipated strong negative elasticities for both retail sales in 1929 and tax returns. After combining the results of the relief and recovery variables with the reform variables, it appears that the programs specifically designed to provide relief actually promoted Roosevelt's three-R objectives. Again, it is difficult to say whether these objectives were fully realized, but the effects we find in the county-level data are much stronger than those seen in analyses using aggregated state data.

This positive record of income redistribution under the relief programs only partially extended to the black population. Despite federal officials' statements that the programs were nondiscriminatory, many of the programmatic decisions were made by state and local officials and there are claims that many of the decisions were discriminatory (Lieberman, 1998; Sterner, et. al., 1943). The CWA and the public assistance programs were positively and statistically significantly related to the percent black variable, but the elasticities were 0.021 and 0.060 , respectively. Meanwhile, the WPA showed a negative and statistically significant relationship with a small elasticity of -0.055 . Finally, none of the relief programs spent more in areas with higher illiteracy.

In the aggregate New Deal statistics, the redistributive aspects of the relief programs are overshadowed by other New Deal programs. For example, the AAA payments to restrict production and Farm Credit Administration loans favored large farmers and high-income areas. ${ }^{17}$ Both sets of programs had positive and statistically significant relationships with the tax return and per capita retail sales variables, with elasticities in the range of .036 to .194 . The strongest relationships, however, are with the average farm size variable with high elasticities of 1.20 and 0.659 for the AAA and the FCA, respectively. ${ }^{18}$ These findings are consistent with research that has found that the farm programs favored larger farmers often at the expense of non-landowning tenants and wage workers. ${ }^{19}$

Similarly, the New Deal loan programs favored high-income counties. If repayment were a concern, then the Roosevelt administration would have tended to lend money where income or the likelihood of economic progress was relatively greater. As a result, we see strong positive relationships between each of the loan programs and the retail sales variable. The elasticities range from a low of 
0.238 for the HOLC mortgage lending to a high of 1.69 in the non-federal PWA loans. The FHA insurance program also displayed a positive and statistically significant elasticity of 0.28 . Not only did these loan programs distribute more resources to counties with relatively higher average incomes, but also to those counties where there was a larger group in the upper portion of the income distribution. The FHA and nearly all of the loan programs had strong positive relationships with the tax return ratio, with elasticities ranging from 0.172 for the RFC to 0.864 for the U.S. Housing Authority. Public housing grants under the PWA (later taken over by the USHA) had very strong positive relationships with the high income measures.

The PWA and other public works programs had a mixed record with regard to income redistribution. Both the federal and non-federal grants programs for the PWA have positive relationships with 1929 retail sales, suggesting that they were not redistributive with respect to average income. On the other hand, they have negative relationships with the tax returns ratio, which suggests that they were distributing away from the highest end of the income distribution. There is also evidence that the federal PWA program tried to help areas with larger black populations, possibly to counteract the lack of nonfederal PWA activity in black areas. The elasticity for percent black was 0.44 for the federal PWA grant program and -0.503 for the non-federal PWA lending program.

Disaggregating spending by program uncovers the relief, recovery, and reform efforts of the New Deal hidden from many previous scholars because of the aggregate nature of their spending data. Relief programs were aimed at lower income areas with higher unemployment and a relatively larger economic downturn in the early 1930s. The farm programs promoted recovery, but were centered on high-income counties with larger farms. Meanwhile, the loan programs, concerned about the likelihood of repayment, distributed more funds to high-income counties and those not hit as hard by the Depression.

\section{V.3 Political and Structural Economic Variables}

Although we have focused on the high-minded goals of the New Deal, there are several key findings concerning the structural economic variables that deserve attention. ${ }^{20}$ The coefficients of the 
economic variables are largely consistent with the findings of other economists and the historical literature on New Deal spending. The relief programs focused on non-farm areas, while the farm programs unsurprisingly targeted agricultural areas. Fleck (2001b) notes that a state's land mass was an important determinant of its New Deal distribution. When we look program by program, the elasticities show that the large effects Fleck found are primarily associated with two programs: the Public Roads Administration grants, which by statute were to be distributed via a formula based on population and land mass, and the PWA grants for projects proposed by federal agencies.

Scholars have suggested a variety of ways to test whether New Deal expenditures were used for naked political purposes. Wright (1974) developed a "political productivity index" at the state level that took into account the long-term support for Democratic presidential candidates between 1896 and 1932, as well as the volatility of that support. Anderson and Tollison (1991) and Couch and Shughart (1998) used Roosevelt's share of the 1932 vote, which is a reasonable specification on the grounds that Roosevelt was likely to reward his supporters and that Roosevelt was seeking more than just a 51 percent victory so that he could establish a mandate. Fleck (2001a) developed a model of swing voting in several layers of government and found swing voters to be important determinants of the distribution of relief jobs. Rhode, Snyder and Strumpf (2001), in their study of military spending during World War II, argue that the focus should be on the swing vote in a median voter model, so they use the gap between the Democratic and Republican votes.

We take a neutral stance on whether the appropriate standard is the median-voter model or the "mandate model," so include a variety of political variables spanning both views. If Roosevelt sought to reward long-time Democratic supporters, we expect more spending in areas where the mean Democratic presidential vote share from 1896 through 1928 was relatively higher. ${ }^{21}$ Had Roosevelt sought to influence swing voters, we expect more per capita spending in counties where the standard deviation of the Democratic vote share from 1896 to 1932 was higher. Roosevelt might have targeted spending in counties based on the difference between his vote share in 1932 and the long-term Democratic vote share from 1896 to 1928 . This measure would have targeted areas where voters actually did switch to support 
Roosevelt in the 1932 election, a group likely to switch again. ${ }^{22}$ Fleck (1999c) shows that a key determinant of FERA spending was voter turnout, which we measure as the number of presidential votes cast in 1932 divided by the population in 1930. This variable measures the extent to which the populace was politically active, which, in turn, would suggest their greater likelihood of successfully lobbying for New Deal support.

From the expansive set of New Deal regressions, two general statements describe the impact of presidential politics. First, in nearly every program at least one political variable affected the distribution of funds in the expected direction. Second, no single presidential political variable exerts a strong influence in every program or, for that matter, in a majority of programs. There is certainly potential for multicollinearity in these measures, but closer examination shows that each variable is measuring a different aspect of presidential politics. Since we are sensitive to the potential for omitted variables bias, we chose to include them all, such that the regressions provide a simultaneous test of all the potential effects.

The programs most responsive to long-term Democratic support (as measured by mean voting from 1896 to 1928) were the AAA, the REA, and most of the public works programs. In the case of the public works programs, the PWA programs, and the PBA all have elasticities ranging from 0.22 to 1.28 , but only the PBA coefficient is statistically significant.

Long-term Democratic supporters were less likely to determine elections than swing voters, however. The swing voters most likely to stay with Roosevelt in 1936 were the ones who swung to Roosevelt in the 1932 election (as measured by the vote for Roosevelt in 1932 minus the mean Democratic vote, 1896-1928). The programs that were most responsive to the Roosevelt swing were the FERA, the WPA, the PRA, the FSA grants, and the REA. The PRA's 0.188 elasticity with respect to the Roosevelt swing vote, as well as the 0.654 elasticity with respect to voter turnout, suggest that there was room within the road-allocation formula to accommodate presidential reelection goals.

Holding constant the Roosevelt swing vote, the standard deviation of votes from 1896 to 1932 measures deeper-seated volatility among a county's voters. The programs most responsive to this 
measure include the PWA federal and non-federal programs, the FCA loan programs, the FSA grant programs, and the U.S. Housing Administration programs. All have elasticities higher than 0.14 and the PWA federal program elasticity is extremely large at 2.53 .

The political measure that seems to have an impact on the most programs is the measure of voter turnout. The variable not only reflects interest in presidential politics, but also interest in the political process more generally. Such localized political interest and savvy might have been associated with greater pressure by the state and local governments on the federal government to obtain more funding. Given the way nearly all of the programs were structured - state and local governments applied for grants and loans - we would expect state and local governments to have played an important role in the overall allocation of New Deal funds. The programs with elasticities above 0.10 included the CWA, SSA public assistance programs, the public works programs at both the federal and non-federal levels, the PRA, the FCA loans, the RFC, the FSA loans, the REA loans, and the FHA. Most of the coefficients on which the elasticities are based are also statistically significant.

The public works programs deserve slightly more discussion on this political dimension. The PWA developed a reputation for focusing on the long-term value of projects, avoiding scandal, and making decisions without regard to politics. In Senate hearings before the Committee on Appropriations concerning the 1935 allocations for the PWA, Senators Townsend and Chairman Glass, an avowed opponent of federal subsidies, each declared that they thought Ickes was free of politics when distributing PWA funds (J. K. Williams, 1968, p. 128). Yet, biographers note that Ickes served Roosevelt faithfully in stump speeches leading up to the 1936 election (Clarke, 1996). The results of the analysis suggest that the federal PWA program, a program over which the Roosevelt administration exercised direct control, was highly sensitive to political interests. The elasticities on each of the political variables are among the highest that we calculated, although not all are precisely estimated. Part of the PWA's reputation for being above politics might have come from looking at the combined spending on the federal and state/local programs. Given that the state and local PWA project selections were driven more from the bottom up, their impact would have muted the effects of the federal programs. In fact, the elasticity for 
the Roosevelt swing vote was negative for the non-federal PWA programs and the other elasticities were much smaller.

\section{Conclusions}

Did the New Deal indeed promote relief, recovery, and reform? The answer largely depends on the program. The major relief programs appear to have been responsive to the ideals of the three Rs. Measures of unemployment, the depth of the depression, and proxies for income consistently affected allocations for relief. Relief programs were not used exclusively for high-minded objectives, political factors were important, but politics seems to have mattered more in the agricultural and public works programs than in the relief programs. Whether the magnitudes of the elasticities with respect to relief and recovery are "enough" to say that the programs were adhering to the three-R mantra is a normative question that will always depend on the eye of the beholder.

Many other New Deal programs display only limited relationships to the relief, recovery, and reform motives. Every loan and housing program distributed more funds in areas with higher levels of per capita retail sales and a higher percentage of households rich enough to pay income taxes. The farm programs typically distributed relatively more money in areas with larger farms and, aside from the FSA, distributed more money to areas with higher average incomes and with a higher share of wealthier citizens. The public works programs also tended to be more generous to areas with higher average retail sales per person. Most of these programs were designed from the start to require state, local, or even private investment before funding could be assured. Most of the loans were expected to be repaid, farmers had to have enough land to take some out of production before the AAA stepped in, and the nonfederal public works programs required significant local sponsorship. To join these programs, communities had to have sufficient resources to meet the financial requirements of the program, hence, the strong relationships between program spending and income.

The New Deal was designed to provide something for everyone. The Roosevelt administration targeted specific programs to the needs of particular groups. The regression results show that relief 
programs clearly benefited the unemployed in urban areas and the AAA aided larger farmers. Geographic areas with larger middle and upper income classes, many of whom also experienced substantial problems during the Depression, received more loans from the RFC and the PWA. Many people with the resources to own homes benefited from HOLC loans and FHA insurance of mortgages. The county-level information highlights the targeted nature of the New Deal's efforts.

There is no doubt that politics was important. At least one of the presidential political variables had an economically and statistically significant impact on nearly every program. Even the Public Works Administration, which was famous for its alleged nonpartisanship, appears to have distributed funds for federally sponsored projects with the presidential elections in mind. Part of the PWA's reputation derived from the funding of non-federal projects, which were often the result of choices made by state and local jurisdictions.

In the final analysis a large fraction of the New Deal money that was spent followed Roosevelt's three-R mandate, but politics was important too. The New Deal's high-minded agenda was not only the result of a focus on public service but also a response to the demands of the populace in the heart of a Great Depression. Roosevelt, Hopkins, Ickes, and the other administrators of the New Deal were savvy politicians who understood the problems their constituents faced. Winning reelection required more than spending extra funds in certain key swing areas, rewarding Democratic supporters, or spending where people turned out more for Roosevelt. To please their nationwide constituency, they had to promote relief and recovery at the very least (redistribution is trickier because it often goes to people who are less likely to vote). They established a plethora of programs, each with a specific problem to solve. Thus, for those concerned with unemployment, Roosevelt and Hopkins could point to the FERA, CWA, and WPA. To those concerned with farm problems, they pointed to the AAA and the FCA. It is important to look at the range of programs that were offered for evidence of Roosevelt's political motivation because within any specific program his administrators had only limited political leeway. Had the largest relief grants gone to the areas with the lowest unemployment, for example, there might have been a scandal sufficient to stymie their reelection hopes. It was good politics to deliver on the high-minded goals, just as it was good 
politics to spend more money at the margin, everything else constant, in areas that were key to the reelection effort. 


\section{DATA APPENDIX}

New Deal spending information is from the U.S. Office of Government Reports (1940). Table 1 shows the total amounts from March 1933 through June 1939 distributed by the various programs. Retail sales information from 1933 is from U.S. Department of Commerce, Bureau of Foreign and Domestic Commerce (1936). The 1929 retail sales information is from Historical, Demographic, Economic, and Social Data: The United States, 1790-1970, ICPSR tape number 0003, as corrected by Michael Haines. The population figures used to create our per capita estimates for 1929 and 1933 retail spending were calculated using linear interpolations of the 1930 and 1940 populations. We calculated 1929 population as 1930 minus the average annual change in population between 1930 and 1940; we did not use trends from 1920 to 1930 due to changes in county boundaries between 1920 and 1930. The percent black, percent urban, percent of a county's land in farms, inverse of population, area in square miles, unemployed as a percent of the gainfully employed, average farm size, and percent of acres with crop failure are from the 1930 files in ICPSR tape 0003 as corrected by Michael Haines. For 1930 we used the illiteracy rate for people aged 10 and above. The tax return information comes from U.S. Department of Commerce, Bureau of Foreign and Domestic Commerce (1932).

The mean Democratic share of the presidential vote from 1896-1928, the percent voting for Roosevelt in 1932 minus the mean Democratic share from 1896 to 1928, the standard deviation of the Democratic share of the presidential vote from 1896 to 1932, and the percent of adults voting in 1932 were all calculated using information from ICPSR's United States Historical Election Returns, 1824-1968 (ICPSR tape number 0001). The variables measuring House tenure and representation on House committees between 1933 and 1938 are from U.S. Congress, Official Congressional Directory, for the $73^{\text {rd }}$ Congress $1^{\text {st }}$ session through $76^{\text {th }}$ Congress. We then matched the congressional information with the counties. For the majority of New Deal programs we used average congressional information from the 1933 to 1938 period. For shorter-lived programs we used congressional information tied to those periods. For example, for the CWA we used the 1933 information, for FERA the 1933-1935 information, for the WPA grants, SSAPA grants, and USHA loans we used 1935-1938 information.

The data set consists of 3,060 counties and county/city combinations in the United States. The New Deal program information was reported for some combined counties. For example, the New Deal information was reported for all of New York City. Thus, in New York state, Bronx, Kings, New York, Queens, and Richmond counties were combined into New York City. Similar situations developed in other states. In Missouri, St. Louis City and County were combined. In Virginia we combined the following districts that were reported separately in the Census, but together in the New Deal data: Albemarle county and Charlottesville city; Allegheny county and Clifton Forge city; Augusta county and Staunton city; Campbell county and Lynchburg city; Dinwiddie county and Petersburg city; Elizabeth City county and Hampton city; Frederick county and Winchester city; Henrico county and Richmond city; Henry county and Martinsville city; James City county and Williamsburg city; Montgomery county and Radford city; Nansemond county and Suffolk city; Norfolk county with Norfolk city, South Norfolk city; and Portsmouth city; Pittsylvania county and Danville city; Prince George county and Hopewell city; Roanoke county and Roanoke city; Rockbridge county and Buena Vista city; Rockingham county and Harrisonburg city; Spotsylvania county and Fredericksburg city; Warwick county and Newport News city; Washington county and Bristol city; Arlington county and Alexandria city. A small number of counties were dropped from the sample due to missing values for the variables above. 


\section{FOOTNOTES}

1 See Arrington (1969) and the studies summarized in Table 2.

${ }^{2}$ As in the prior literature, we focus on the distribution of funds without examining the tax collection side of the analysis. Federal tax rates were uniform nationwide, so variations in federal tax revenue from the counties would have been driven by the number of families with incomes large enough to pay income taxes (less than 7 percent nationwide), the extent of corporate activity, and differences in the consumption of goods subject to excise taxes. We are also not trying to capture the indirect effects of payments that might arise from changes in markets in response to the grants and loans.

${ }^{3}$ Another issue to consider is that not all federal dollars were alike. A dollar from the WPA was likely to have a bigger economic effect than an AAA dollar. The AAA dollar was essentially a payment to a farmer to take land out of production, thus the net benefit of the AAA dollar to the farmer was less than a dollar. Similarly, in this analysis we take a look at specific loan programs for the first time. Since the majority of loans that were made were to be repaid, it is clear that loan dollars had quite a different meaning than grant dollars.

${ }^{4}$ For an appreciation of the variety of strategies followed by state and local governments in response to the New Deal, see Patterson (1967), and the case studies on North Carolina by Abrams (1992), on

Arizona by Collins (1999), on the South by Biles (1994), and the series of studies of Massachusetts, Ohio, Virginia, Pennsylvania, Louisiana, Oklahoma, Wyoming, Montana, Colorado, New Mexico, Oregon, and Missouri edited by Braeman, Bremner, and Brody (1975).

${ }^{5}$ Wallis (1984) used a simultaneous equations model that explicitly examined matching; Wallis (1987 and 1998) used lagged grants to try to capture the pressures from state governments; and Fleck (1999b and 1999c) used state dummies in his county-level analysis to control for state government activities. Couch and Shughart (1998) looked at the sponsor's role in the WPA, but in another analysis they had panel data but did not use state effects or lagged grants to control for state interests in the New Deal.

${ }^{6}$ For analyses of the factors influencing work relief, unemployment, and private employment at the individual level for WPA workers in 1940, see Margo (1991), Finegan and Margo (1994), and Sundstrom (1995).

${ }^{7}$ See Graham (1973) and Sitkoff (1985) for debates about the New Deal.

${ }^{8}$ For innovative approaches to theoretical modeling of the political process in this context, see the work of Wright (1974), Fleck (1999a, 1999b, 2001a) and Rhode, Snyder, and Strumpf (2001).

${ }^{9}$ Estimating separate structural equations for each program, but directly taking into account the fact that all programs were substitutes, would involve finding instrumental variables for each individual program. That would be a most difficult task.

${ }^{10}$ For a discussion of the political nature of this variable, see Fleck (2001b) and Wallis (2001).

${ }^{11}$ The Social Security Administration's public assistance programs required explicit matching from the states. The FERA was originally designed such that half of the initial monies were to be distributed with a strong matching grant component and the other half was to be distributed on a discretionary basis. However, after spending \$200 million on a matching basis by November 1933, FERA administrator Harry Hopkins convinced Congress to allow the FERA to distribute the monies on a discretionary basis, which is how the vast majority of FERA funds were spent. See U.S. Senate (1935, pp. xi-xiv), E. A. Williams (1968, pp. 181-90, 203-17), and Couch and Shughart (1998). The WPA also asked state and local governments to contribute funding to its projects, although there was never an explicit matching formula and the federal share of the funding of projects varied substantially across states (Howard, 1943, pp. 146-50).

${ }^{12}$ Because we are estimating separate equations for multiple programs, we might have needed to pay attention to potential cross-equation error correlations by using a seemingly unrelated regression (SUR) analysis. However, since all of the equations we estimate have the same set of independent variables, the SUR estimator is the same as the OLS estimator. 
${ }^{13}$ Wright (1974), Wallis (2001), and Fleck (2001b) have followed the procedure of comparing the Rsquareds from regressions with just the political variables to regressions with just the economics and structural variables to see which sets of variables explain more of the variation in the sample. We have performed similar comparisons (see Appendix Table 6) in which we compared the adjusted R-squareds from regressions with only the presidential and congressional variables listed in Table 3 (percent voting democrat for president 1896-1928 through the Congressional committee assignments) to regressions with only the structural and reform, relief, and recovery variables (inverse population through average farm size). The adjusted R-squared from the structural and three-R specifications are larger than those from the political specifications in all but the SSA public assistance regression. We did not include the state dummy variables in either regression because they control simultaneously for both political and nonpolitical factors. In the county studies, F-tests reject the hypothesis that all of the state effects are simultaneously zero in nearly all cases.

${ }^{14}$ The WPA lasted through 1942, but our data set only records spending through June 1939 for any program. The Social Security programs include Aid to Dependent Children, Aid to the Blind, and OldAge Assistance.

${ }^{15}$ Harold Ickes administered the PWA, with advice from a Special Board. Generally, the projects were vetted by each of three sections of the central office and then sent on to the Special Board. Roosevelt had the final say and E. A. Williams (1968, 106 and 114-16) claimed that Roosevelt did not just "rubber stamp" Ickes's decisions. In discussing how the PWA funds were distributed, Williams argued that the Special Board did not focus on the variables that the National Planning Board deemed important to consider, such as population, unemployment, relief spending, tax contributions, or land area, but that the Special Board did take note occasionally of its comparative generosity to some states and restricted or postponed allotments accordingly.

${ }^{16}$ The tax information has been used by a number of scholars (Smiley 2000, Schmitz and Fishback 1983) as proxies for the share of income in the highest tail of the income distribution.

${ }^{17}$ Unlike most New Deal agencies, the AAA was administered by an existing department - the Department of Agriculture - which established state and local committees or associations of producers to help administer the act. The AAA Rental and Benefit payments were distributed to farmers who agreed to participate in a program of controlled production. Farmers voluntarily signed production agreements in which they would curtail the acreage they planted. The benefit payments were financed from special processing taxes on the commodity being curtailed. The goal of the program was to increase the incomes of farmers both through benefit payments and by raising market prices to pre-World War I levels (1920s levels for tobacco). There was a general belief that most of the burden of the processing taxes would be passed on to consumers of farm products. For detailed discussions of the AAA administration, see Nourse, et. al. (1937, pp. 39-40, 92-114, 120-46, 287-323).

${ }^{18}$ The measure of farm size is problematic in southern plantation areas where there were large numbers of sharecroppers who were treated by the census as farm operators, when in fact they were more like farm laborers. See Alston and Kaufmann (1997).

${ }^{19}$ See Saloutos (1974 and 1982), Alston (1981), Whatley (1983), and Biles (1994).

${ }^{20}$ A key theme of Anderson and Tollison's (1991) work was that it was important to include Congressional pressures. We include them in several ways. For the House of Representatives we include measures of the tenure of congressmen representing the district in which the county was located. House members with longer tenures had more seniority on committees at this time. Weingast and Marshall's (1988) discussion of the organization of Congress suggests that committee members wield significant power over the passage of bills and over the administration of administrative programs. Members of committees have more clout than the typical representative in determining how monies will be distributed, either through writing the rules for distributing funds in advance of the bill or through pressures to spend the money after the program is in place. To capture this effect, we include representation on a series of key committees in the House of Representatives at the opening of the $73^{\text {rd }}$ 
Congress in 1933. The same issues obviously exist for the Senate. The impact of the Senate influences is among several factors that are captured by the state dummy variables.

The impact of House tenure was relatively small on the distribution process. The elasticity was higher than 0.05 for only the U.S. Housing Authority loans. The coefficients of the congressional committee variables suggest that for most programs there was one and sometimes more committees that appeared to increase spending in the area in a statistically significant way. Membership on the Agriculture Committee was associated with an extra $\$ 20$ per capita in AAA spending, \$6.5 in FCA loans, and $\$ 1.23$ in REA loans. Appropriations Committee membership was associated with an extra \$6.86 in non-federal PWA loans. The Irrigation and Control Committee raised FSA grants by $\$ 0.86$. The Labor Committee appeared to influence the most programs, raising FERA, CWA, and AAA grants and USHA loans. The Public Lands Committee raised FERA spending, PRA spending and AAA spending. The Roads Committee increased WPA, RFC, and HOLC funds. Finally, Ways and Means primarily influenced the public buildings and public housing grants.

We have experimented with using the Poole and Rosenthal (1997) measures of ideological location in political space, but the elasticities were all low and the coefficients were typically statistically insignificant. We also experimented with a dummy variable accounting for southern Democratic congressmen, but the variable had little impact.

${ }^{21}$ This is similar to a key component of Wright's presidential political productivity index. Other key components included the number of electoral votes in each state and the standard deviation of the democratic voting.

${ }^{22}$ Wright's political productivity index for analysis at the state level was weighted by the votes in the Electoral College. We have experimented with using an electoral votes measure for each county that multiplied the state's electoral votes by the county's share of the population. Given the way electoral votes were determined, this essentially becomes a measure of population share nationwide. Inclusion of the variable leads to results that yield largely the same inferences as reported here. 


\section{REFERENCES}

Abrams, D. C., 1992. Conservative Constraints: North Carolina and the New Deal. University Press of Mississippi, Jackson MS.

Alston, L. J., 1981. Tenure choice in southern agriculture, 1930-1960. Explorations in Economic History 18, 211-32.

Alston, L. J., Kauffman K., 1997. Agricultural chutes and ladders: New estimates of sharecroppers and "true tenants" in the South, 1900-1920. Journal of Economic History 57, 464-75.

Anderson, G. M., Tollison, R. D., 1991. Congressional influence and patterns of New Deal spending, 1933-1939. Journal of Law and Economics 34, 161-75.

Arrington, L. J., 1970. Western agriculture and the New Deal. Agricultural History 49, 337-16.

Bernstein, B., 1990. The New Deal: The conservative achievements of liberal reform. In: Dubofsky, M., Burwood, S. (Eds.), The Great Depression and the New Deal. Garland Publishing, New York, pp. 64-89.

Biles, R., 1994. The South and the New Deal. University of Kentucky Press, Lexington, KY.

Braeman, J., Bremner, R. H., Brody, D. (Eds.), 1975. The New Deal: The State and Local Levels, volume two. Ohio State University Press, Columbus, OH.

Brown, J. C., 1940. Public Relief, 1929-1939. H. Holt and Company, New York.

Clarke, J. N., 1996. Roosevelt's Warrior: Harold L. Ickes and the New Deal. Johns Hopkins University Press, Baltimore.

Collins, W. S., 1999. The New Deal in Arizona. Arizona State Parks Board, Phoenix.

Conkin, P. K., 1967. FDR and the Origins of the Welfare State. Crowell, New York.

Couch, J., Atkinson, K. E., Wells, W. H., 1998. New Deal agricultural appropriations: A political influence. Eastern Economic Journal 24, 137-48.

Couch, J., Shughart, W., 1998. The Political Economy of the New Deal. Edward Elgar, New York.

Couch, J., Williams, P. M., 1999. New Deal or same old shuffle? The distribution of New Deal dollars across Alabama. Economics and Politics 11, 213-23.

Degler, C. N. 1959. Out of Our Past: The Forces that Shaped the Modern America. Harper, New York.

Finegan, T. A., Margo, R. A., 1994. Work relief and the labor force participation of married women. Journal of Economic History 54, 64-84.

Fleck, R. K., 1999a. Electoral incentives, public policy, and the New Deal realignment. Southern Economic Journal 63, 377-404.

Fleck, R. K., 1999b. The marginal effect of New Deal relief work on county-level unemployment statistics. Journal of Economic History 59, 659-87.

Fleck, R. K., 1999c. The value of the vote: A model and test of the effects of turnout on distributive policy. Economic Inquiry 37, 609-23.

Fleck, R. K., 2001a. Inter-party competition, intra-party competition, and distributive policy: A model and test using New Deal data. Public Choice 108, 77-100.

Fleck, R. K., 2001b. Population, land, economic conditions, and the allocation of New Deal spending. Explorations in Economic History 38, 296-304.

Freidel, F., 1971. Franklin D. Roosevelt: Launching the New Deal. Little, Brown, Boston.

Graham, O. (Ed.), 1973. The New Deal: The Critical Issues. Little, Brown, Boston.

Howard, D. S., 1943. The WPA and Federal Relief Policy. Russell Sage Foundation, New York..

Inter-University Consortium for Political and Social Research (ICPSR). Historical, Demographic, Economic, and Social Data: The United States, 1790-1970, ICPSR dataset number 0003, as corrected by Michael Haines, Department of Economics, Colgate University, Hamilton, NY.

Inter-University Consortium for Political and Social Research (ICPSR). United States Historical Election Returns, 1824-1968, ICPSR Dataset Number 0001.

Key, V. O., 1937. The Administration of Federal Grants to States. Social Science Research Council, Chicago.

Leuchtenburg, W. E., 1963. Franklin Roosevelt and the New Deal, 1932-1940. Harper and Row, New 
York

Lieberman, R. C., 1998. Shifting the Color Line: Race and the American Welfare State. Harvard University Press, Cambridge, MA.

McJimsey, G. T., 1987. Harry Hopkins: Ally of the Poor and Defender of Democracy. Harvard University Press, Cambridge, MA.

Margo, R. A., 1991. The microeconomics of depression unemployment. Journal of Economic History $51,333-41$

Mason, J., 2002. The political economy of Reconstruction Finance Corporation assistance during the Great Depression. Drexel University Working Paper.

Nourse, E. G., Davis, J. S., Black, J. D., 1937. Three Years of the Agricultural Adjustment Administration. Brookings Institution, Washington, D.C.

Patterson, J. T., 1967. Congressional Conservatism and the New Deal: The Growth of the Conservative Coalition in Congress, 1933-1939. University of Kentucky Press, Lexington, KY.

Poole, K. T., Rosenthal, H., 1997. Congress: A Political-Economic History of Roll Call Voting. Oxford University Press, New York.

Reading, D. C., 1973. New Deal activity and the states, 1933 to 1939. Journal of Economic History 33, 792-810.

Rhode, P., Snyder, J., Strumpf, K. 2001. 'The Great Arsenal of Democracy?' The political economy of the county-level allocation of World War Two military spending. Working Paper presented at the NBER-DAE 2001 Summer Institute.

Roosevelt, F. D., 1934. Review of the achievements of the seventy-third congress. June 28, 1934 Fireside Chat. Available at http://newdeal.feri.org.

Saloutos, T., 1982. The American Farmer and the New Deal. Iowa State University Press, Ames, IA.

Saloutos, T., 1974. New Deal agricultural policy: An evaluation. Journal of American History 61, 394416.

Schlesinger, A. M., Jr., 1958. The Age of Roosevelt: The Coming of the New Deal. Houghton-Mifflin, Boston..

Schmitz, M., Fishback, P. V., 1983. The distribution of income in the Great Depression: Preliminary state estimates. Journal of Economic History 43, 217-30.

Sitkoff, H. (Ed.), 1985. Fifty Years Later: The New Deal Evaluated. Knopf, New York.

Smiley, G., 2000. A note on new estimates of the distribution of income in the 1920s. Journal of Economic History 60, 1120-28.

Sterner, R. M. E., Epstein, L. A., Winston, E., 1943. The Negro's Share: A Study of Income, Consumption, Housing, and Public Assistance. Harper and Brothers, New York.

Strömberg, D., 2001. Radio's impact on public spending. Institute for International Economic Studies, Stockholm University Working paper.

Sundstrom, W., 1995. Did the WPA displace private employment? Evidence from the 1940 census microsample. Santa Clara University Working Paper.

U.S. Congress., various years. Official Congressional Directory, $73^{\text {rd }}$ Congress $1^{\text {st }}$ session through $76^{\text {th }}$ Congress. GPO, Washington, DC.

U.S. Department of Commerce, Bureau of Foreign and Domestic Commerce, 1932. General Consumer Market Statistics, Supplement 1 to the Market Data Handbook of the United States. GPO, Washington, DC.

U.S. Department of Commerce, Bureau of Foreign and Domestic Commerce, 1936. Consumer Market Data Handbook. GPO, Washington, DC.

U.S. Office of Government Reports, Statistical Section, 1940. Report No. 10, Volume 1, 'County reports of estimated federal expenditures, March 4, 1933 - June 30, 1939'. Mimeo.

U.S. Senate, 1935. Expenditure of Funds: Federal Emergency Relief Administration. Senate Document No. $56,74^{\text {th }}$ Congress $1^{\text {st }}$ session. GPO, Washington, DC.

Wallis, J. J., 1984. The birth of the old federalism: Financing the New Deal, 1932-1940. Journal of Economic History 44, 139-59. 
Wallis, J. J., 1987. Employment, politics, and economic recovery during the Great Depression. Review of Economics and Statistics 69, 516-20.

Wallis, J. J., 1989. Employment in the Great Depression: New data and hypotheses. Explorations in Economic History 26, 45-72.

Wallis, J. J., 1998. The political economy of New Deal spending revisited, again: With and without Nevada. Explorations in Economic History 35, 140-70.

Wallis, J. J., 2001. The political economy of New Deal spending, yet again: A reply. Explorations in Economic History 38, 305-14.

Wallis, J. J., Oates, W. E., 1998. The Impact of the New Deal on American Federalism. In: Bordo, M. D., Goldin, C., White, E. N. (Eds.), The Defining Moment: The Great Depression and the American Economy in the Twentieth Century. University of Chicago Press, Chicago, pp. 155-80.

Weingast, B. R., Marshall, W. J., 1988. The industrial organization of Congress; or, why legislatures, like firms, are not organized as markets. Journal of Political Economy 96, 132-63.

Whatley, W. C., 1983. Labor for the picking: The New Deal in the South. Journal of Economic History 43, 905-29.

Williams, E. A., 1968. Federal Aid for Relief. AMS Press, New York.

Williams, J. K., 1968. Grants-in-Aid Under the Public Works Administration: A Study in Federal-StateLocal Relations. AMS Press, New York.

Wright, G., 1974. The political economy of New Deal spending: An econometric analysis. Review of Economics and Statistics 56, 30-38.

Zinn, H., 1966. New Deal Thought. Bobbs-Merrill, New York. 

Table 1

Total Federal Grants, Loans, and Value of Mortgages Insured, March 1933 - June 1939, by Program

\begin{tabular}{|c|c|c|}
\hline NON-REPAYABLE GRANTS: & Grant Dollars & $\begin{array}{r}\% \text { of } \\
\text { Grants }\end{array}$ \\
\hline Agricultural Adjustment Adm. (AAA) & $\$ 1,981,801,905$ & 12.1 \\
\hline Farm Security Adm. (FSA) Grants & $93,408,281$ & 0.6 \\
\hline U.S. Housing Authority (USHA) & $127,206,671$ & 0.8 \\
\hline Public Building Adm. (PBA) Federal Buildings & $174,228,825$ & 1.1 \\
\hline Public Roads Adm. (PRA) & $1,556,290,368$ & 9.5 \\
\hline Public Works Adm. (PWA) Federal Projects & $798,501,411$ & 4.9 \\
\hline Public Works Adm. (PWA) Non-Federal Projects & $1,367,347,520$ & 8.4 \\
\hline Civil Works Adm. (CWA) & $757,172,702$ & 4.6 \\
\hline Federal Emergency Relief Adm. (FERA) & $2,654,860,349$ & 16.3 \\
\hline Social Security Adm. Public Assistance (SSAPA) & $596,010,054$ & 3.6 \\
\hline Works Progress Adm. (WPA) & $6,222,385,662$ & 38.1 \\
\hline Total Grants & $16,329,213,748$ & 100.0 \\
\hline LOANS: & Loan Dollars & $\begin{array}{r}\% \text { of } \\
\text { Loans }\end{array}$ \\
\hline Farm Credit Adm. (FCA) Loans & $\$ 1,257,491,136$ & 12.0 \\
\hline Farm Security Adm. (FSA) Loans & $427,932,675$ & 4.1 \\
\hline Rural Electrification Adm. (REA) Loans & $226,247,292$ & 2.2 \\
\hline Home Owners Loan Corporation (HOLC) & $3,077,258,287$ & 29.5 \\
\hline U.S. Housing Authority (USHA) Loans & $449,854,991$ & 4.3 \\
\hline Disaster Loan Corp. (DLC) & $\$ 10,504,466$ & 0.1 \\
\hline Reconstruction Finance Corp. (RFC) & $4,425,940,596$ & 42.4 \\
\hline $\begin{array}{l}\text { Public Work Adm. (PWA) Non-Federal Program } \\
\text { Loans }\end{array}$ & $567,616,807$ & 5.4 \\
\hline Total Loans & $10,442,846,250$ & 100.0 \\
\hline 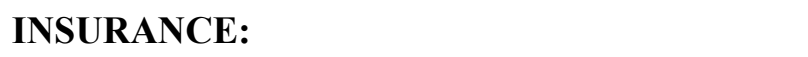 & & \\
\hline $\begin{array}{l}\text { Federal Housing Adm. (FHA) Insurance: Value of } \\
\text { Loans Insured }\end{array}$ & $\$ 2,707,560,412$ & \\
\hline
\end{tabular}

Note: The RFC loans began in February 1932.

Source: U.S. Office of Government Reports (1940). 


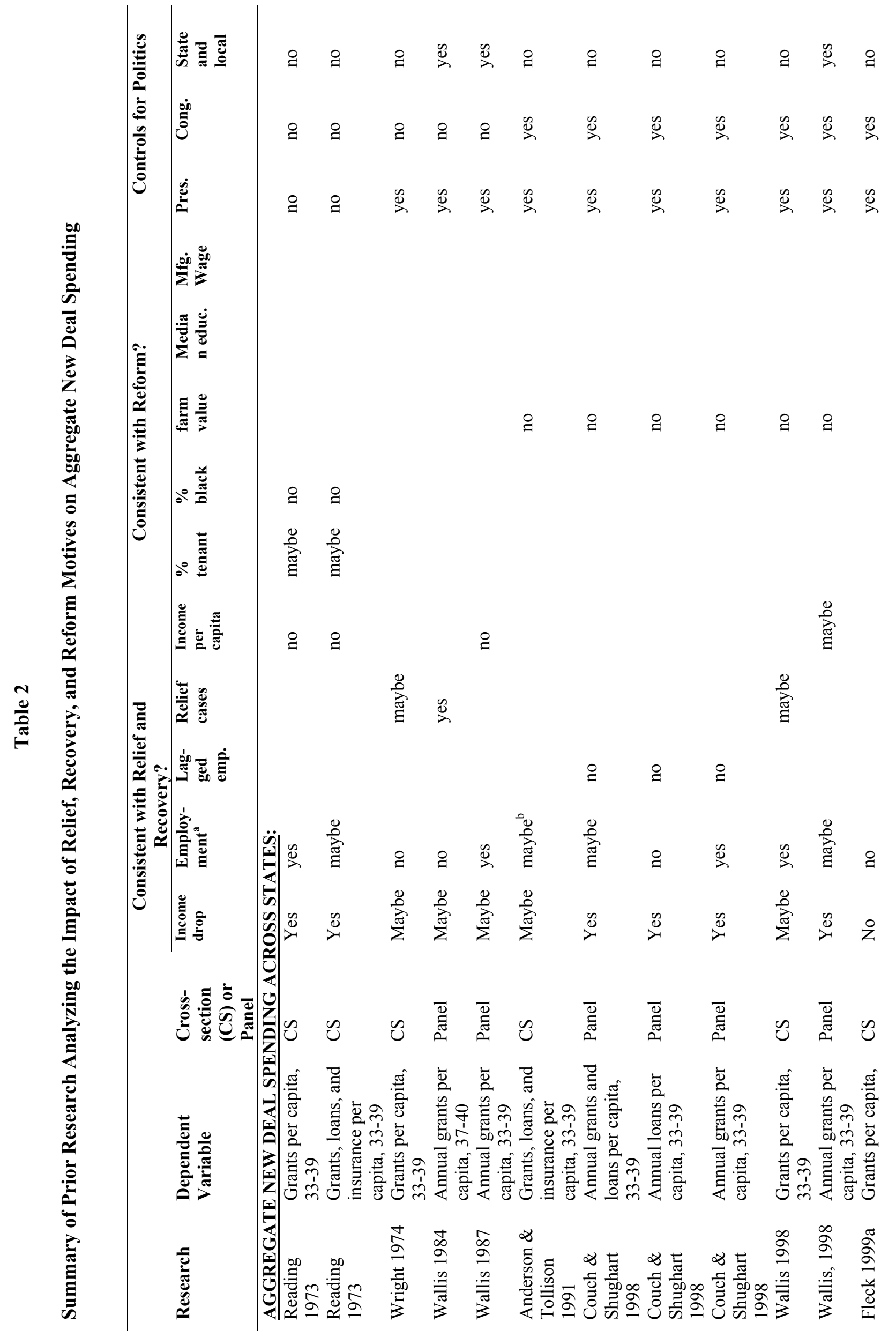




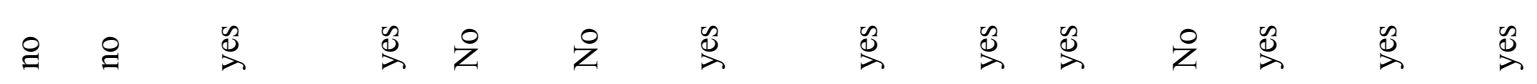

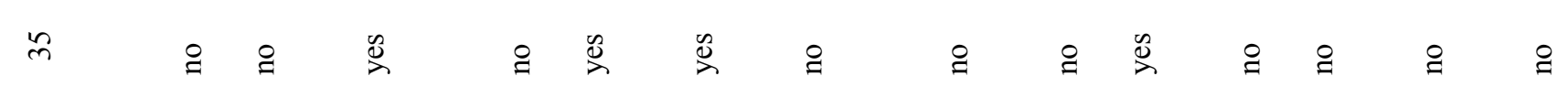

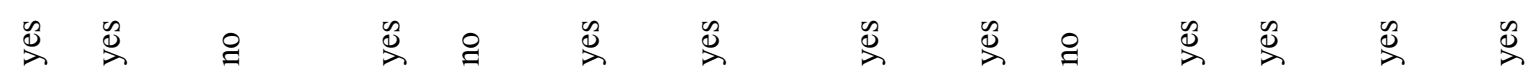

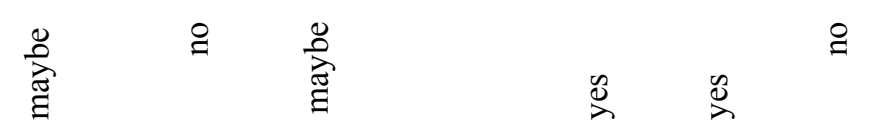

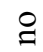
$\cong \quad$ 善善咅 $2 \%$ 品

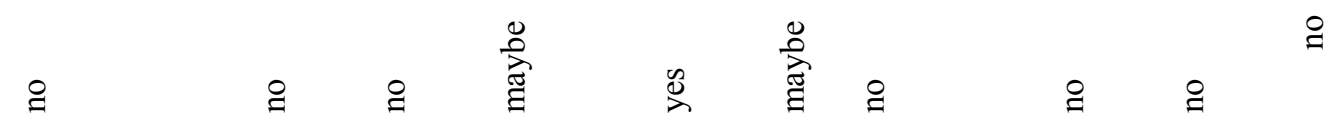

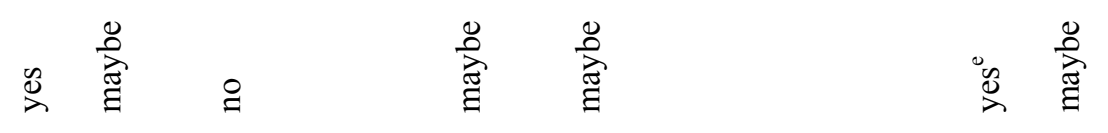

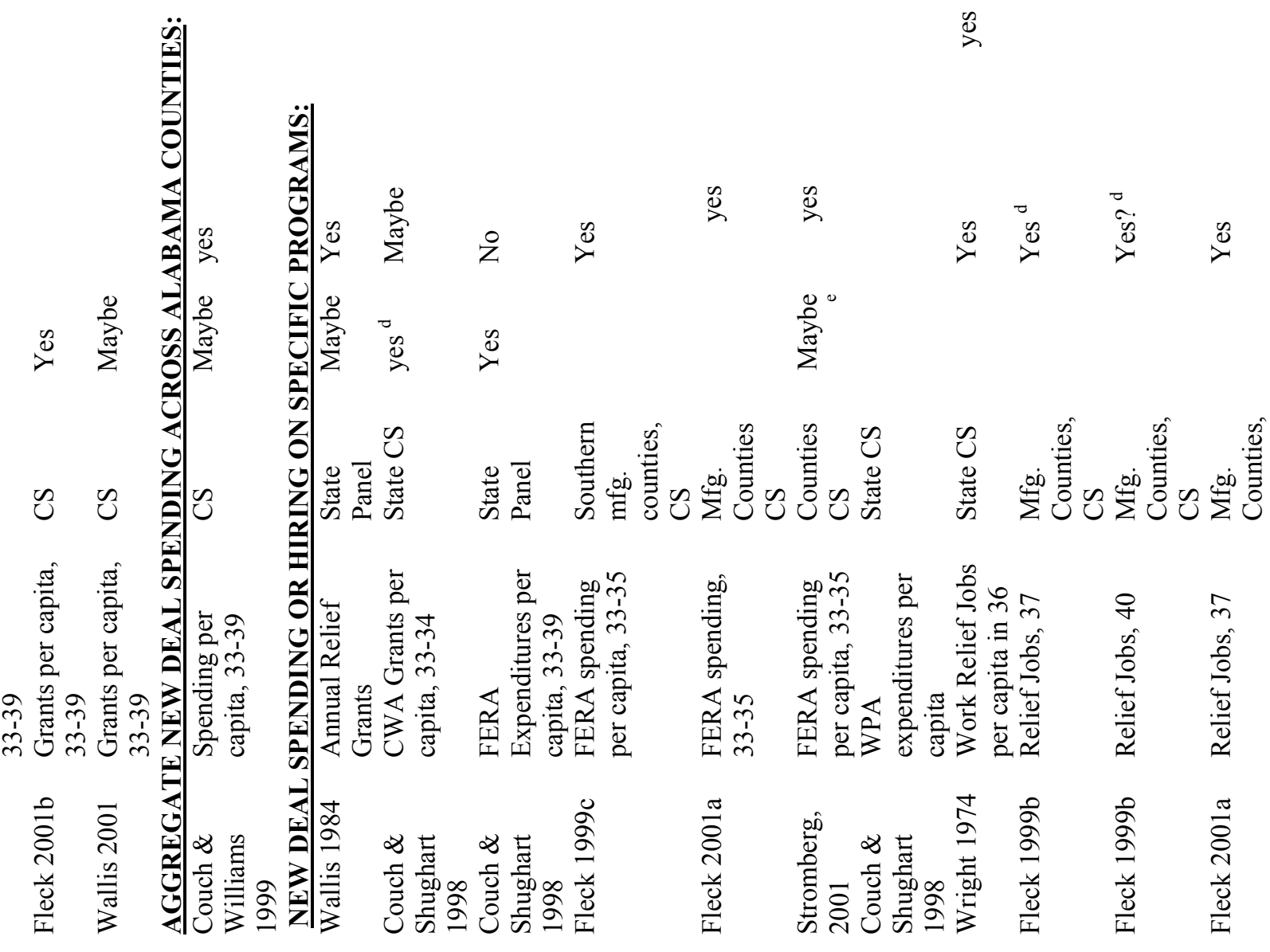




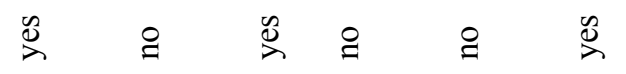

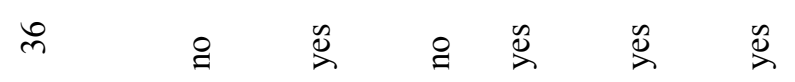

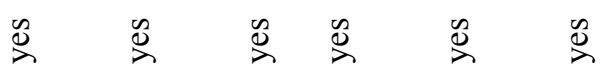

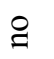

产

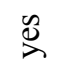

\&

z

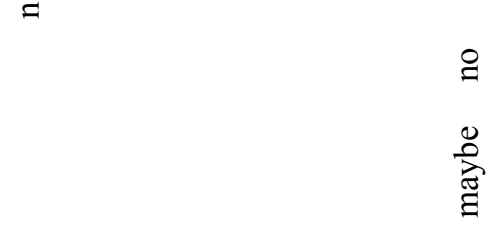

ֻ

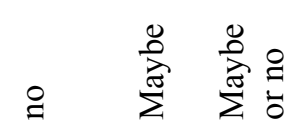

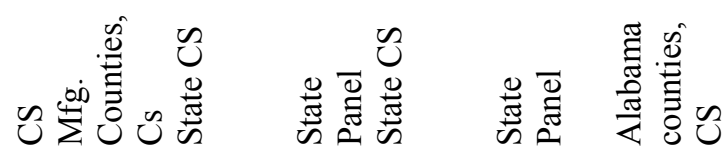

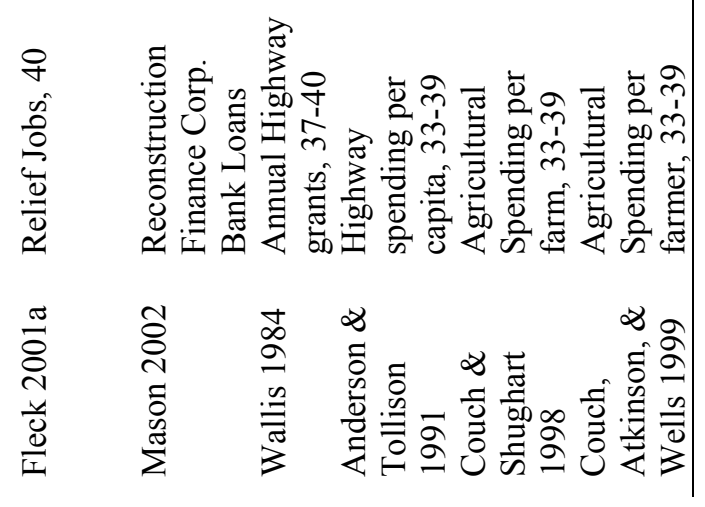

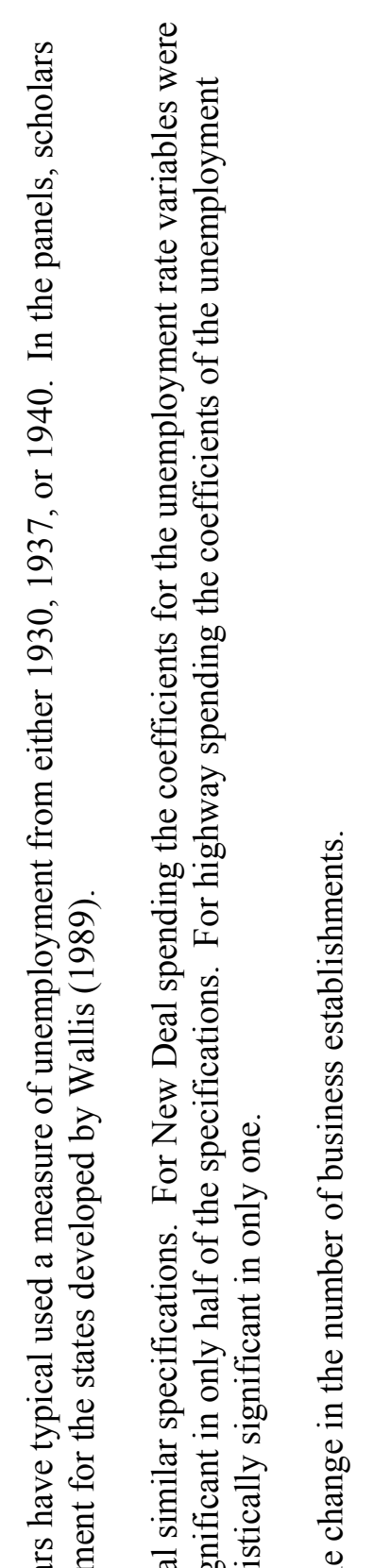

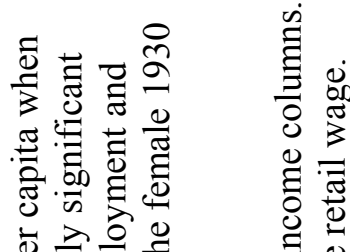

के

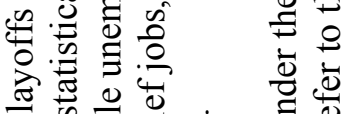

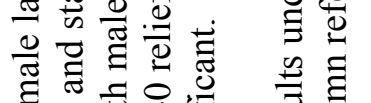

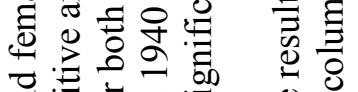

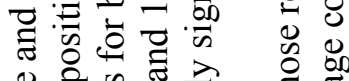

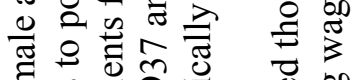

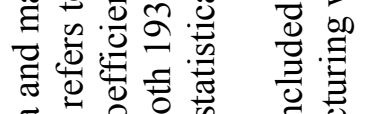

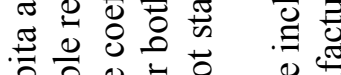

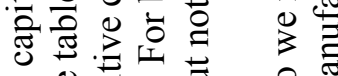

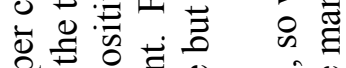

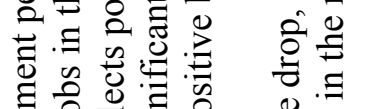

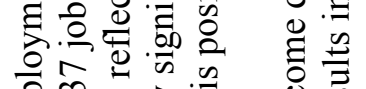

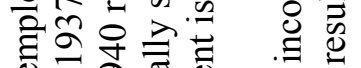

छ

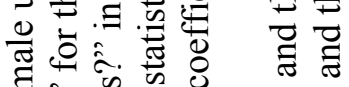

यै कि

善 3 离

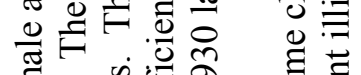

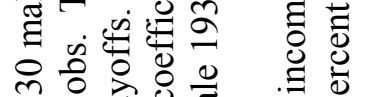

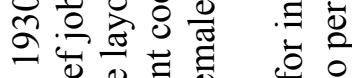

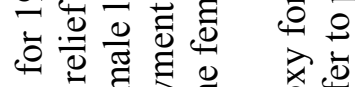

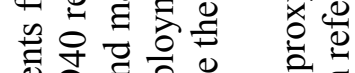

.

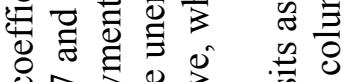

ठ ठิ

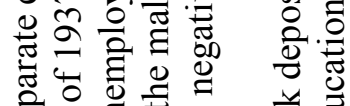

क्षे

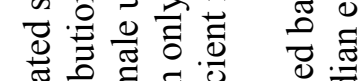

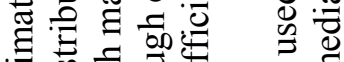

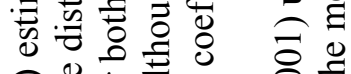

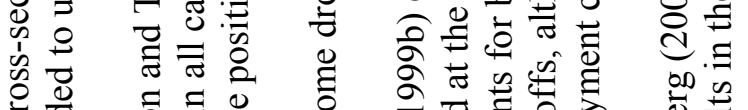

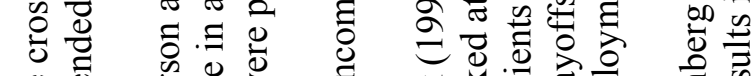

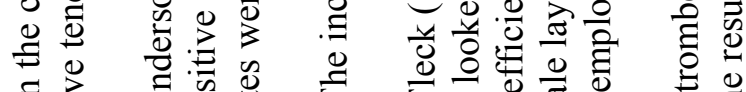

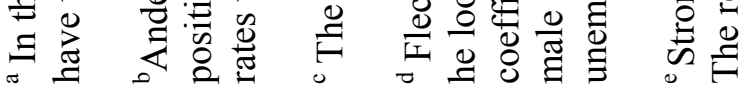


n

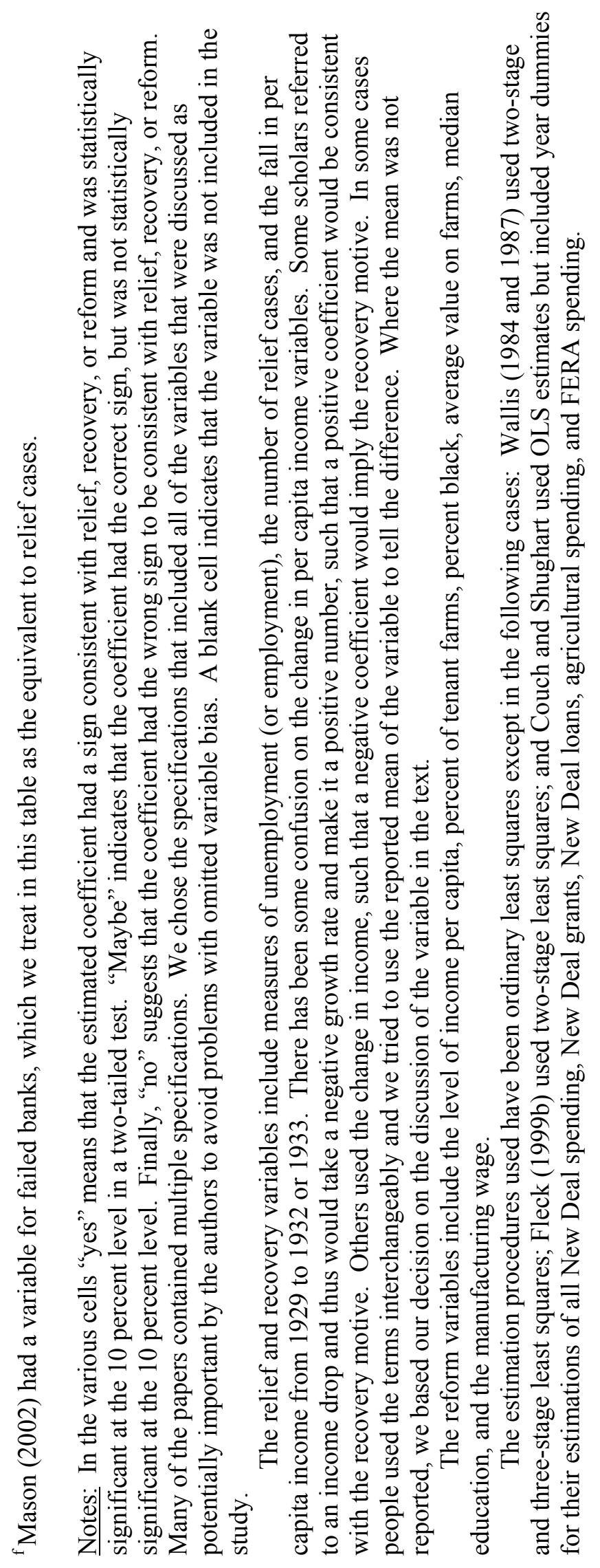


Table 3

Summary Statistics and Interpretations of Independent Variables Included in the Regression Analysis of Each New Deal Program

\begin{tabular}{|c|c|c|c|}
\hline Variables & Sign and meaning of Coefficients & Mean & Std. Dev. \\
\hline \multicolumn{4}{|l|}{ Structural Economic: } \\
\hline Inverse of population, 1930 & $\begin{array}{l}\text { Positive suggests program provided } \\
\text { base level of spending }\end{array}$ & 8.90 & 14.0 \\
\hline Area in square miles per capita, 1930 & $\begin{array}{l}\text { Positive suggests rewarding large } \\
\text { areas with less population density }\end{array}$ & 0.10 & 0.27 \\
\hline Percent of land in farms, 1929 & $\begin{array}{l}\text { Positive suggests focused on farm } \\
\text { areas }\end{array}$ & 64.5 & 27.3 \\
\hline Percent Urban, 1930 & $\begin{array}{l}\text { Positive suggests focused on urban } \\
\text { areas }\end{array}$ & 21.0 & 24.8 \\
\hline \multicolumn{4}{|l|}{ Reform Motive: } \\
\hline Tax returns filed per capita, 1929 & Negative suggests redistribution & 1.41 & 1.32 \\
\hline Retail Sales per capita, 1929 & Negative suggests redistribution & 541.2 & 269.8 \\
\hline Percent black, 1930 & Positive suggests redistribution & 11.1 & 18.4 \\
\hline Percent illiterate, 1930 & Positive suggests redistribution & 5.41 & 5.83 \\
\hline \multicolumn{4}{|l|}{ Relief and Recovery Motives: } \\
\hline $\begin{array}{l}\text { Difference in log retail sales per capita, } \\
1933-1929\end{array}$ & $\begin{array}{l}\text { Negative suggests promoted relief } \\
\text { and recovery }\end{array}$ & -0.47 & 0.24 \\
\hline $\begin{array}{l}\text { Unemployed as percent of gainfully } \\
\text { employed, } 1930\end{array}$ & $\begin{array}{l}\text { Positive suggests promoted relief and } \\
\text { recovery }\end{array}$ & 2.79 & 2.20 \\
\hline $\begin{array}{l}\text { Percent of farm acres with crop failures, } \\
1929\end{array}$ & $\begin{array}{l}\text { Positive suggests promoted relief and } \\
\text { recovery }\end{array}$ & 3.19 & 4.07 \\
\hline Average farm size, 1929 & $\begin{array}{l}\text { Positive suggests larger farms } \\
\text { benefited disproportionately }\end{array}$ & 82.3 & 88.6 \\
\hline \multicolumn{4}{|l|}{ Political Influence: } \\
\hline $\begin{array}{l}\text { Mean Democratic presidential vote } \\
\text { percentage, } 1896-1928\end{array}$ & $\begin{array}{l}\text { Positive suggests rewarded long-term } \\
\text { Democratic voters }\end{array}$ & 49.4 & 18.5 \\
\hline $\begin{array}{l}\text { Percent voting for Roosevelt in } 1932 \\
\text { minus above mean from } 1896-1928\end{array}$ & $\begin{array}{l}\text { Positive suggests rewarded voters } \\
\text { who swung to Roosevelt in } 1932\end{array}$ & 18.8 & 10.3 \\
\hline $\begin{array}{l}\text { Standard deviation of presidential voting } \\
\text { percentage for Democrats, } 1896-1932\end{array}$ & $\begin{array}{l}\text { Positive suggests focused on long- } \\
\text { term volatility of swing voters }\end{array}$ & 11.7 & 4.90 \\
\hline $\begin{array}{l}\text { Votes cast in } 1932 \text { presidential election / } \\
1930 \text { population }\end{array}$ & $\begin{array}{l}\text { Positive suggests rewarded voter } \\
\text { activism }\end{array}$ & 31.6 & 15.0 \\
\hline $\begin{array}{l}\text { Average months of consecutive tenure in } \\
\text { the House during period of program }\end{array}$ & $\begin{array}{l}\text { Positive suggests House members } \\
\text { with more seniority brought more } \\
\text { dollars }\end{array}$ & 51.9 & 64.6 \\
\hline $\begin{array}{l}\text { House committee assignments during } \\
\text { period of program }\end{array}$ & $\begin{array}{l}\text { Positive suggests congressional clout } \\
\text { increased funds }\end{array}$ & & \\
\hline Vector of State Dummies & $\begin{array}{l}\text { Controls for unmeasured differences a } \\
\text { to the counties within each state, inclu } \\
\text { representation }\end{array}$ & $\begin{array}{l}\text { S states c } \\
\text { Senate }\end{array}$ & common \\
\hline
\end{tabular}

Note: There are 3,060 observations.

Sources: See Data Appendix. 


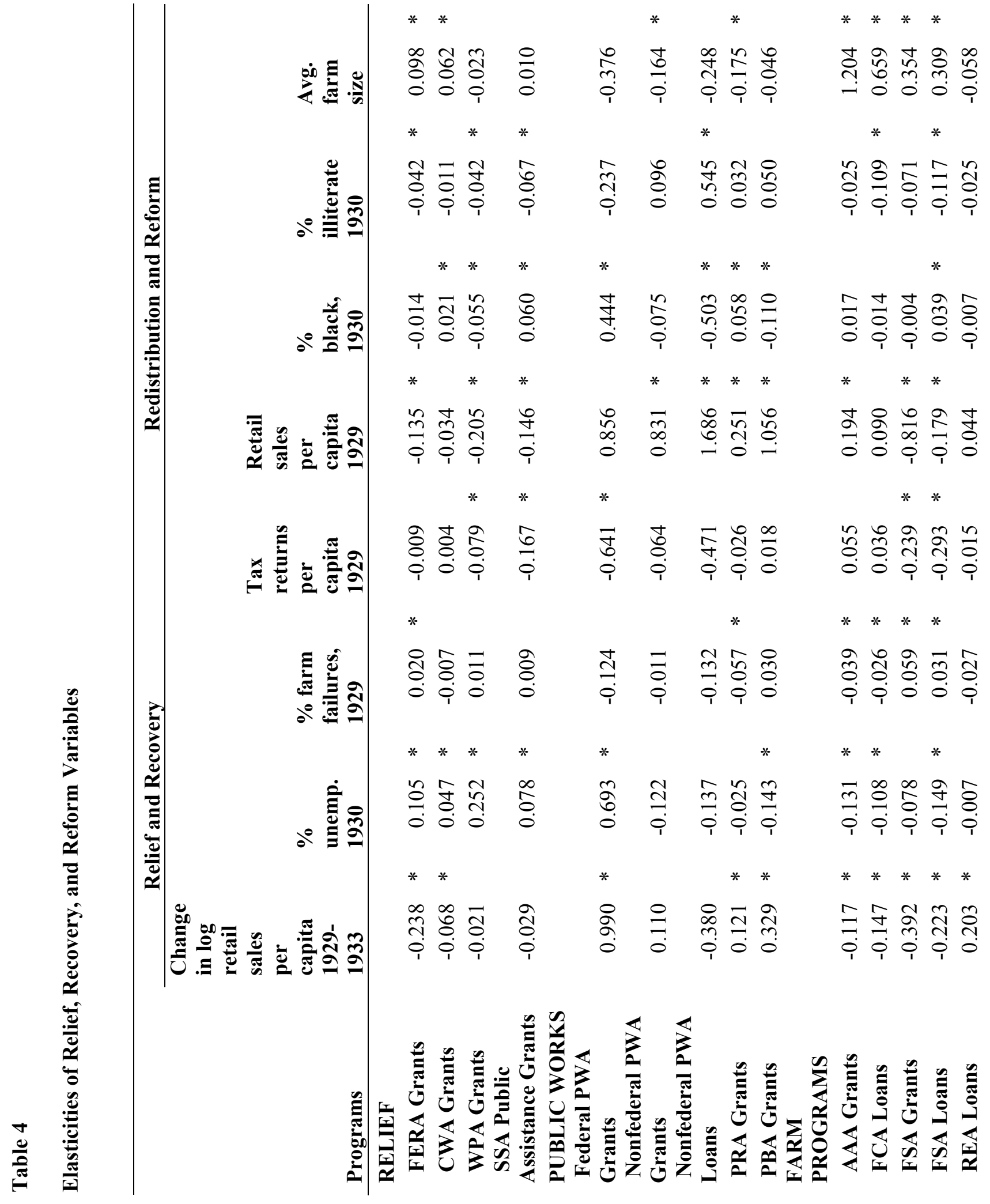




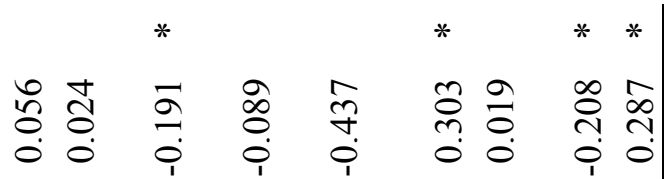

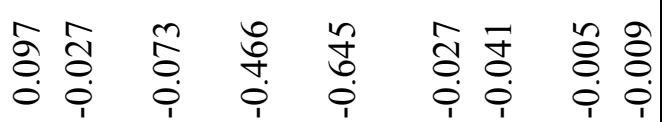

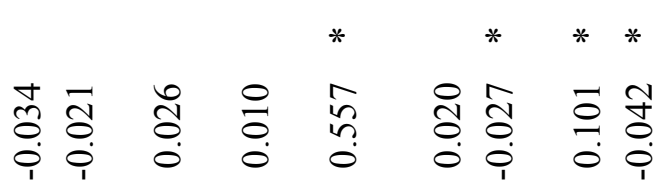

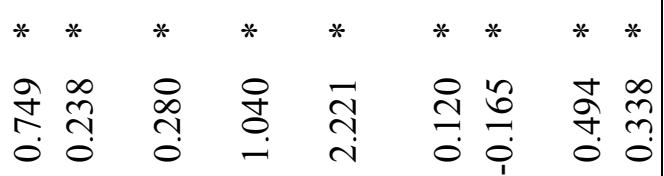

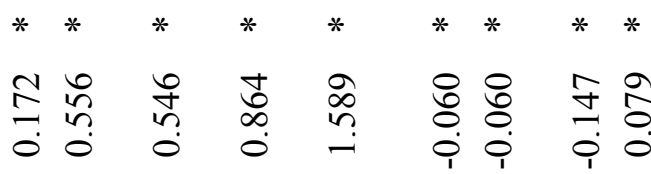

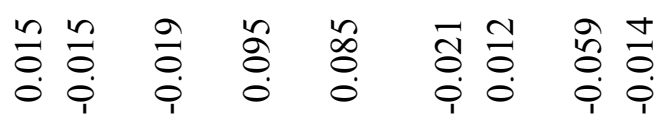

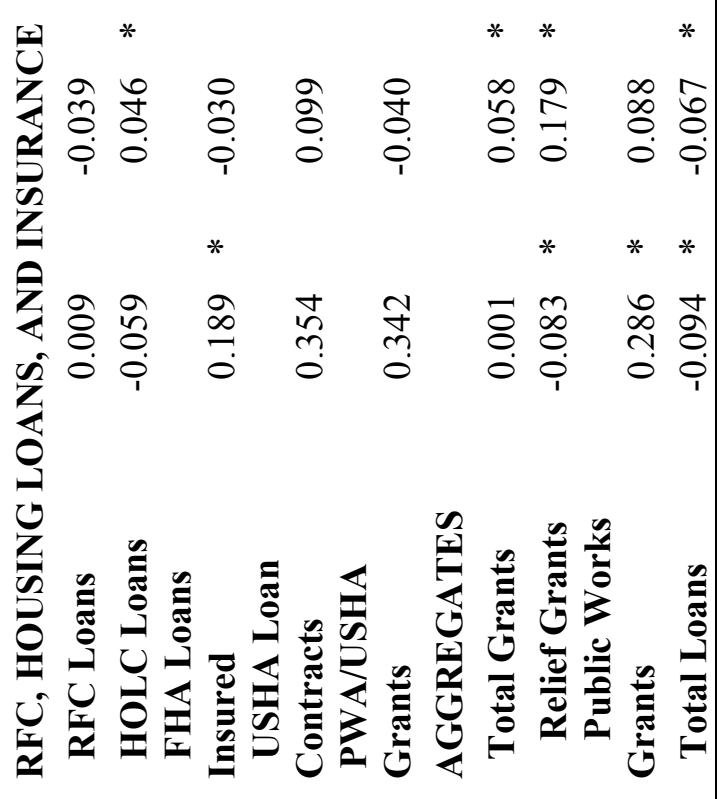

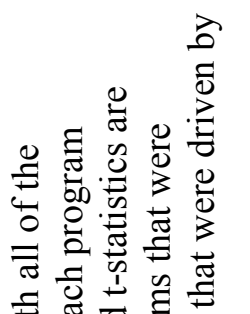

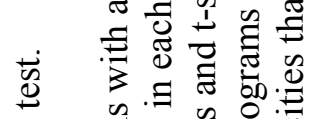

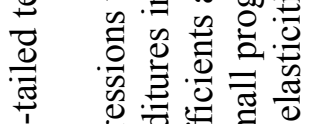

क्ष

远

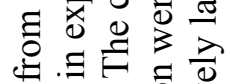

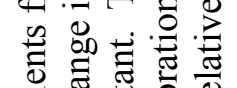

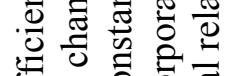

乎 000 过

बं ठ

สิ

离离离

芯导

อ हैं0

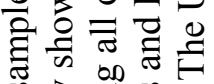

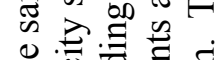

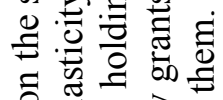

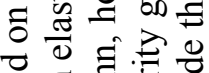

总

에

항

:

.

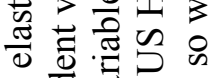

E

웡

.

芯

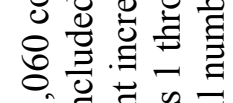

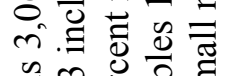

.

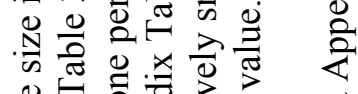

嘣

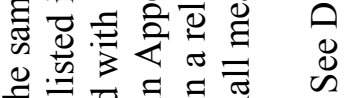

E.

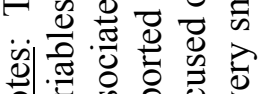

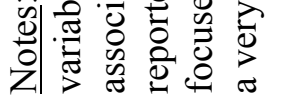


Table 5

Elasticities for Presidential Political Variables and Tenure in the House

\begin{tabular}{|c|c|c|c|c|c|c|c|c|c|c|}
\hline Programs & $\begin{array}{l}\text { Mean } \\
\text { Demo. } \\
\text { \% for } \\
\text { Pres. } \\
1896- \\
1928 \\
\end{array}$ & & $\begin{array}{l}\text { Roosevelt } \\
\text { swing }\end{array}$ & & $\begin{array}{l}\text { Std. } \\
\text { dev. } \\
\text { Demo. } \\
\% \text { for } \\
\text { Pres. } \\
1896- \\
1932\end{array}$ & & $\begin{array}{l}\text { Presidential } \\
\text { votes } 1932 \\
\text { divided by } \\
\text { population } \\
1930\end{array}$ & & $\begin{array}{l}\text { Average } \\
\text { tenure } \\
\text { in } \\
\text { House, } \\
1933 \\
\end{array}$ & \\
\hline \multicolumn{11}{|l|}{ RELIEF } \\
\hline FERA Grants & 0.012 & & 0.209 & $*$ & -0.104 & $*$ & 0.071 & & 0.011 & \\
\hline CWA Grants & -0.026 & & 0.064 & $*$ & -0.074 & $*$ & 0.375 & $*$ & -0.002 & \\
\hline $\begin{array}{l}\text { WPA Grants } \\
\text { SSA Pub. Asst. }\end{array}$ & 0.005 & & 0.165 & $*$ & -0.234 & $*$ & -0.050 & & -0.007 & \\
\hline Grants & 0.036 & & 0.016 & & -0.062 & & 0.719 & $*$ & 0.011 & \\
\hline \multicolumn{11}{|c|}{$\begin{array}{l}\text { PUBLIC WORKS } \\
\text { Federal PWA }\end{array}$} \\
\hline $\begin{array}{l}\text { Grants } \\
\text { Nonfederal PW }\end{array}$ & 0.708 & & 0.997 & & 2.526 & $*$ & 8.417 & $*$ & 0.019 & \\
\hline $\begin{array}{l}\text { Grants } \\
\text { Nonfederal PW }\end{array}$ & 0.220 & & -0.292 & $*$ & 0.276 & & 0.430 & & -0.060 & \\
\hline Loans & 1.280 & & -0.302 & & 0.146 & & 0.792 & & -0.187 & \\
\hline PRA Grants & 0.094 & & 0.188 & $*$ & -0.170 & $*$ & 0.654 & $*$ & 0.003 & \\
\hline $\begin{array}{l}\text { PBA Grants } \\
\text { FARM } \\
\text { PROGRAMS }\end{array}$ & 0.772 & $*$ & -0.001 & & -0.102 & & 0.105 & & -0.022 & \\
\hline AAA Grants & 0.262 & $*$ & 0.269 & $*$ & -0.085 & & 0.096 & & 0.047 & $*$ \\
\hline FCA Loans & -0.009 & & 0.046 & & 0.227 & $*$ & 0.191 & $*$ & 0.017 & \\
\hline FSA Grants & 0.007 & & 0.361 & $*$ & 0.283 & $*$ & -0.449 & $*$ & -0.001 & \\
\hline FSA Loans & 0.100 & & 0.013 & & 0.090 & & 0.139 & & -0.041 & * \\
\hline \multicolumn{11}{|c|}{$\begin{array}{l}\text { RFC, HOUSING LOANS, AND } \\
\text { INSURANCE }\end{array}$} \\
\hline RFC Loans & -0.108 & & -0.107 & & 0.206 & & 0.216 & & 0.004 & \\
\hline $\begin{array}{l}\text { HOLC Loans } \\
\text { FHA Loans }\end{array}$ & -0.180 & $*$ & -0.045 & & -0.071 & & -0.327 & $*$ & -0.011 & \\
\hline $\begin{array}{l}\text { Insured } \\
\text { USHA Loan }\end{array}$ & -0.209 & & -0.103 & & 0.143 & & 0.299 & & -0.056 & $*$ \\
\hline $\begin{array}{l}\text { Contracts } \\
\text { PWA/USHA }\end{array}$ & 0.074 & & 0.128 & & 0.483 & & -1.408 & $*$ & 0.009 & \\
\hline Grants & -0.063 & & 0.737 & & 0.477 & & -0.738 & & 0.071 & \\
\hline \multicolumn{11}{|l|}{ AGGREGATES } \\
\hline Total Grants & 0.140 & $*$ & 0.226 & $*$ & 0.016 & & 0.580 & $*$ & 0.009 & \\
\hline Relief Grants & 0.007 & & 0.154 & $*$ & -0.170 & $*$ & 0.088 & & 0.000 & \\
\hline
\end{tabular}




\begin{tabular}{|c|c|c|c|c|c|c|c|c|}
\hline $\begin{array}{l}\text { Public Work } \\
\text { Grants }\end{array}$ & 0.248 & 0.242 & $*$ & 0.420 & $*$ & 2.045 & $*$ & -0.007 \\
\hline Total Loans & 0.090 & -0.001 & & 0.139 & $*$ & 0.183 & $*$ & -0.008 \\
\hline
\end{tabular}

$*=$ coefficient upon which the elasticity is based is statistically significant at the 10 percent level, or better, in a two-tailed test.

Notes: The sample size is 3,060 counties. The elasticities are based on the sample means and coefficients from regressions with all of the variables listed in Table 3 included as independent variables. Each elasticity shows the percentage change in expenditures in each program associated with a one percent increase in the variable in each column, holding all other variables constant. The coefficients and tstatistics are reported in Appendix Tables 1 through 5.

Sources: See Data Appendix. 
Table 6

Elasticities for Structural Economic Variables

\begin{tabular}{|c|c|c|c|c|c|c|c|c|}
\hline Programs & $\begin{array}{l}\text { Inverse } \\
\text { population }\end{array}$ & & $\begin{array}{l}\text { Square } \\
\text { miles } \\
\text { per } \\
\text { capita }\end{array}$ & & $\begin{array}{l}\text { \% } \\
\text { urban } \\
1930 \\
\end{array}$ & & $\begin{array}{l}\text { \% } \\
\text { land } \\
\text { in } \\
\text { farms, } \\
1929\end{array}$ & \\
\hline \multicolumn{9}{|l|}{ RELIEF } \\
\hline FERA Grants & 0.023 & $*$ & 0.008 & & 0.095 & $*$ & -0.564 & $*$ \\
\hline CWA Grants & 0.058 & $*$ & -0.005 & & 0.072 & $*$ & -0.449 & $*$ \\
\hline $\begin{array}{l}\text { WPA Grants } \\
\text { SSA Pub. Asst. }\end{array}$ & -0.018 & & -0.020 & $*$ & 0.109 & $*$ & -0.594 & $*$ \\
\hline Grants & 0.022 & $*$ & 0.002 & & 0.019 & & -0.194 & * \\
\hline \multicolumn{9}{|c|}{$\begin{array}{l}\text { PUBLIC WORKS } \\
\text { Federal PWA }\end{array}$} \\
\hline $\begin{array}{l}\text { Grants } \\
\text { Nonfederal PWA }\end{array}$ & -0.971 & $*$ & 0.822 & $*$ & 0.071 & & -0.272 & \\
\hline $\begin{array}{l}\text { Grants } \\
\text { Nonfederal PWA }\end{array}$ & -0.005 & & -0.010 & & 0.073 & & -0.010 & \\
\hline Loans & -0.071 & & 0.044 & & 0.076 & & -0.501 & \\
\hline PRA Grants & 0.335 & $*$ & 0.252 & $*$ & -0.030 & & -0.067 & \\
\hline $\begin{array}{l}\text { PBA Grants } \\
\text { FARM } \\
\text { PROGRAMS }\end{array}$ & -0.117 & $*$ & 0.023 & & -0.006 & & -0.598 & * \\
\hline AAA Grants & 0.056 & $*$ & -0.050 & $*$ & -0.193 & $*$ & -0.113 & $*$ \\
\hline FCA Loans & 0.054 & $*$ & 0.027 & $*$ & -0.189 & $*$ & 0.172 & $*$ \\
\hline FSA Grants & 0.021 & & 0.000 & & 0.095 & $*$ & -0.328 & * \\
\hline FSA Loans & 0.006 & & 0.003 & & -0.051 & $*$ & -0.073 & \\
\hline \multicolumn{9}{|c|}{$\begin{array}{l}\text { RFC, HOUSING LOANS, AND } \\
\text { INSURANCE }\end{array}$} \\
\hline RFC Loans & 0.034 & & -0.049 & $*$ & 0.203 & $*$ & -0.424 & $*$ \\
\hline $\begin{array}{l}\text { HOLC Loans } \\
\text { FHA Loans }\end{array}$ & -0.006 & & -0.030 & $*$ & 0.368 & $*$ & -0.168 & * \\
\hline $\begin{array}{l}\text { Insured } \\
\text { USHA Loan }\end{array}$ & 0.049 & $*$ & -0.072 & $*$ & 0.241 & $*$ & -0.164 & \\
\hline $\begin{array}{l}\text { Contracts } \\
\text { PWA/USHA }\end{array}$ & 0.082 & & 0.034 & & 1.323 & $*$ & -1.737 & * \\
\hline Grants & 0.165 & & 0.082 & & 0.793 & $*$ & -0.926 & \\
\hline \multicolumn{9}{|l|}{ AGGREGATES } \\
\hline Total Grants & 0.024 & $*$ & 0.067 & $*$ & -0.004 & & -0.278 & * \\
\hline Relief Grants & 0.003 & & -0.010 & & 0.094 & $*$ & -0.538 & $*$ \\
\hline Public Works & 0.016 & & 0.302 & $*$ & 0.009 & & -0.106 & \\
\hline
\end{tabular}




\section{Grants}

Total Loans

$0.024 *-0.004$

0.020 $-0.083$

$*=$ coefficient upon which the elasticity is based is statistically significant at the 10 percent level, or better, in a two-tailed test.

Notes: The sample size is 3,060 counties. The elasticities are based on the sample means and coefficients from regressions with all of the variables listed in Table 3 included as independent variables. Each elasticity shows the percentage change in expenditures in each program associated with a one percent increase in the variable in each column, holding all other variables constant. The coefficients and tstatistics are reported in Appendix Tables 1 through 5.

Sources: See Data Appendix. 
Appendix Table 1

OLS Regression Results for Relief Programs

\begin{tabular}{|c|c|c|c|c|c|c|c|c|}
\hline & \multicolumn{2}{|c|}{ FERA Grants } & \multicolumn{2}{|c|}{ CWA Grants } & \multicolumn{2}{|c|}{ WPA Grants } & \multicolumn{2}{|c|}{ SSAPA Grants } \\
\hline & Coeff. & t-stat. & Coeff. & t-stat. & Coeff. & t-stat. & Coeff. & t-stat. \\
\hline $\begin{array}{l}\text { Intercept } \\
\text { Inverse }\end{array}$ & 11.1134 & 2.27 & 2.5133 & 2.08 & 50.1770 & 4.10 & 3.8958 & 2.82 \\
\hline Population & 0.0421 & 1.94 & 0.0392 & 7.33 & -0.0704 & -1.30 & 0.0132 & 2.16 \\
\hline $\begin{array}{l}\text { Square miles per } \\
\text { capita }\end{array}$ & 1.2293 & 0.96 & -0.2713 & -0.85 & -6.9397 & -2.15 & 0.1125 & 0.31 \\
\hline$\%$ Urban & 0.0743 & 4.80 & 0.0208 & 5.45 & 0.1815 & 4.69 & 0.0049 & 1.13 \\
\hline $\begin{array}{l}\text { \% Land on Farms } \\
\text { Tax returns per }\end{array}$ & -0.1433 & 11.74 & -0.0420 & -13.92 & -0.3224 & -10.54 & -0.0163 & -4.71 \\
\hline capita & -0.1019 & -0.30 & 0.0180 & 0.22 & -1.9694 & -2.34 & -0.6399 & -6.75 \\
\hline $\begin{array}{l}\text { Retail Sales per } \\
\text { capita, } 1929\end{array}$ & -0.0041 & -2.28 & -0.0004 & -0.86 & -0.0133 & -2.95 & -0.0015 & -2.88 \\
\hline$\%$ Black & -0.0208 & -0.90 & 0.0116 & 2.02 & -0.1723 & -2.96 & 0.0293 & 4.45 \\
\hline $\begin{array}{l}\text { \% Illiterate } \\
\text { Growth retail } \\
\text { sales per cap., }\end{array}$ & -0.1262 & -1.97 & -0.0119 & -0.75 & -0.2717 & -1.69 & -0.0671 & -3.70 \\
\hline $1929-33$ & -8.2329 & -7.40 & -0.8642 & -3.15 & -1.5523 & -0.56 & -0.3316 & -1.05 \\
\hline $\begin{array}{l}\text { Unemployment } \\
\text { rate }\end{array}$ & 0.6167 & 4.44 & 0.1012 & 2.95 & 3.1618 & 9.09 & 0.1507 & 3.84 \\
\hline$\%$ Farm failures & 0.1031 & 1.74 & -0.0140 & -0.96 & 0.1233 & 0.83 & 0.0150 & 0.89 \\
\hline $\begin{array}{l}\text { Average farm Size } \\
\text { Mean Demo. \% } \\
\text { for Pres, 1896- } \\
1928\end{array}$ & 0.0196 & 4.84 & 0.0046 & 4.57 & -0.0100 & -0.99 & 0.0006 & 0.56 \\
\hline $\begin{array}{l}\text { Roosevelt Swing } \\
\text { Std. Dev. Demo. } \\
\text { \% for Pres. 1896- }\end{array}$ & 0.1823 & 4.51 & 0.0205 & 2.05 & 0.3074 & 3.04 & 0.0046 & 0.41 \\
\hline $\begin{array}{l}1932 \\
\text { Pres. Votes } \\
\text { 1932/population }\end{array}$ & -0.1451 & -1.67 & -0.0379 & -1.77 & -0.6980 & -3.21 & -0.0285 & -1.16 \\
\hline $\begin{array}{l}1930 \\
\text { Avg. Tenure in }\end{array}$ & 0.0370 & 0.76 & 0.0717 & 5.95 & -0.0557 & -0.46 & 0.1230 & 8.90 \\
\hline $\begin{array}{l}\text { House } \\
\text { Congressional } \\
\text { Committees }\end{array}$ & 0.0035 & 0.84 & -0.0002 & -0.21 & -0.0045 & -0.43 & 0.0012 & 1.00 \\
\hline Agriculture & -0.7091 & -0.78 & -0.5266 & -2.35 & 0.0316 & 0.01 & -0.3410 & -1.33 \\
\hline $\begin{array}{l}\text { Appropriations } \\
\text { Banking and }\end{array}$ & -2.4323 & -2.59 & -0.8100 & -3.49 & 0.7042 & 0.30 & 0.1373 & 0.52 \\
\hline Currency & -1.6283 & -1.42 & -0.1719 & -0.61 & -8.0389 & -2.79 & -0.1342 & -0.41 \\
\hline
\end{tabular}




\begin{tabular}{|c|c|c|c|c|c|c|c|c|}
\hline Exports & -1.2407 & -0.99 & -0.3270 & -1.06 & -1.8414 & -0.59 & -0.2912 & -0.82 \\
\hline Flood Control & -0.8263 & -0.71 & -0.0327 & -0.11 & -1.8954 & -0.65 & 0.5766 & 1.76 \\
\hline Irrigation Control & -1.9970 & -1.86 & -1.0767 & -4.06 & -2.9604 & -1.10 & 0.0346 & 0.11 \\
\hline Labor & 3.4260 & 2.75 & 0.5478 & 1.78 & 3.1127 & 1.00 & 0.1506 & 0.43 \\
\hline Public Buildings & -2.5463 & -2.03 & -0.2250 & -0.73 & -1.2583 & -0.40 & 0.1251 & 0.35 \\
\hline $\begin{array}{l}\text { Public Lands } \\
\text { Rivers and }\end{array}$ & 1.9164 & 1.86 & 0.3053 & 1.20 & -1.1271 & -0.44 & 0.2375 & 0.81 \\
\hline Harbors & 0.9491 & 0.91 & -0.0919 & -0.36 & 0.2533 & 0.10 & -0.1089 & -0.37 \\
\hline Roads & 1.6519 & 1.57 & -0.2937 & -1.13 & 5.1519 & 1.96 & 0.8301 & 2.80 \\
\hline Ways and Means & 0.3237 & 0.28 & 0.1803 & 0.64 & 1.3886 & 0.48 & -0.0355 & -0.11 \\
\hline \multicolumn{9}{|l|}{ State Dummies } \\
\hline ME & 0.4662 & 0.09 & -0.5944 & -0.48 & 1.8339 & 0.15 & -1.4692 & -1.03 \\
\hline MA & 7.8608 & 1.53 & 0.4572 & 0.36 & 29.5264 & 2.30 & 5.6351 & 3.88 \\
\hline NH & -4.2652 & -0.78 & 0.4869 & 0.36 & -9.5239 & -0.69 & -2.9745 & -1.92 \\
\hline RI & -7.5885 & -1.17 & -1.4472 & -0.90 & -4.7561 & -0.29 & -2.8955 & -1.57 \\
\hline VT & -1.7300 & -0.34 & 0.6952 & 0.55 & -3.1342 & -0.24 & -1.8019 & -1.25 \\
\hline DE & 5.8826 & 0.74 & -1.4975 & -0.76 & 12.9152 & 0.65 & -1.8049 & -0.80 \\
\hline NJ & 4.8594 & 1.02 & 0.9806 & 0.83 & 15.8763 & 1.33 & -2.4588 & -1.82 \\
\hline NY & 0.8308 & 0.18 & 0.7113 & 0.63 & -0.6754 & -0.06 & -1.7658 & -1.37 \\
\hline PA & 12.5036 & 2.90 & 0.6544 & 0.61 & 33.9527 & 3.14 & -1.2539 & -1.03 \\
\hline IL & 1.7303 & 0.38 & 1.1909 & 1.06 & 21.1993 & 1.87 & -1.2518 & -0.98 \\
\hline IN & -0.3541 & -0.08 & 2.0244 & 1.89 & 23.5719 & 2.16 & -2.8241 & -2.30 \\
\hline MI & 11.3893 & 2.64 & 7.1026 & 6.67 & 21.4098 & 1.98 & -0.3199 & -0.26 \\
\hline OH & 10.0859 & 2.25 & 3.4655 & 3.13 & 28.5320 & 2.54 & 3.1833 & 2.51 \\
\hline WI & 8.8932 & 2.02 & 5.9446 & 5.48 & 18.1522 & 1.65 & 1.7176 & 1.38 \\
\hline IA & -1.5531 & -0.36 & 1.3456 & 1.26 & 4.0715 & 0.38 & -0.5531 & -0.45 \\
\hline KS & 8.2819 & 1.90 & 2.3421 & 2.18 & 21.6482 & 1.99 & -3.6972 & -3.01 \\
\hline MN & 6.6973 & 1.23 & 2.3331 & 1.74 & 16.8066 & 1.24 & 3.3958 & 2.21 \\
\hline MO & -0.6065 & -0.12 & 1.1842 & 0.92 & 15.6639 & 1.20 & -2.1275 & -1.44 \\
\hline NE & -1.0501 & -0.24 & 0.0767 & 0.07 & 15.8358 & 1.43 & 1.2085 & 0.97 \\
\hline NDK & 17.0072 & 3.52 & 3.8932 & 3.27 & 32.9788 & 2.73 & -3.0946 & -2.27 \\
\hline SD & 31.1441 & 6.89 & 7.6785 & 6.89 & 47.7913 & 4.22 & -1.6064 & -1.26 \\
\hline $\mathbf{V A}$ & 3.3491 & 0.70 & 4.7236 & 4.02 & -3.8780 & -0.33 & -3.4625 & -2.57 \\
\hline $\mathbf{A L}$ & 3.4697 & 0.76 & 4.1329 & 3.65 & -3.3894 & -0.30 & -3.0288 & -2.34 \\
\hline $\mathbf{A R}$ & 3.9310 & 0.87 & 3.9603 & 3.56 & -0.2717 & -0.02 & -3.0216 & -2.37 \\
\hline FL & 17.4146 & 3.88 & 4.9829 & 4.50 & -3.6165 & -0.32 & -0.1041 & -0.08 \\
\hline GA & 0.6073 & 0.14 & 2.3184 & 2.11 & -5.2920 & -0.48 & -3.1631 & -2.52 \\
\hline $\mathbf{L A}$ & 4.6846 & 1.02 & 2.3609 & 2.09 & -7.4363 & -0.65 & -1.7824 & -1.38 \\
\hline MS & 2.8654 & 0.62 & 2.2431 & 1.96 & 4.1759 & 0.36 & -3.6074 & -2.76 \\
\hline NC & 0.9038 & 0.21 & 1.1237 & 1.05 & -5.8848 & -0.54 & -4.8338 & -3.95 \\
\hline SC & 13.7815 & 2.88 & 4.7020 & 3.99 & 8.8730 & 0.74 & -2.6041 & -1.93 \\
\hline $\mathbf{T X}$ & 2.8768 & 0.63 & 3.9456 & 3.53 & 6.3028 & 0.56 & 1.1693 & 0.91 \\
\hline KY & 8.6120 & 1.75 & 1.9306 & 1.59 & 15.8042 & 1.28 & -4.8428 & -3.49 \\
\hline
\end{tabular}




\begin{tabular}{lrlllllrr} 
MD & $\mathbf{3 . 8 4 0 3}$ & 0.81 & $\mathbf{0 . 4 6 5 1}$ & 0.40 & $\mathbf{6 . 2 3 9 1}$ & 0.53 & $\mathbf{- 1 . 1 9 0 7}$ & -0.89 \\
OK & $\mathbf{3 . 6 7 5 6}$ & 0.84 & $\mathbf{4 . 3 5 1 0}$ & 4.01 & $\mathbf{1 6 . 4 3 3 4}$ & 1.49 & $\mathbf{2 . 6 2 5 6}$ & 2.11 \\
TN & $\mathbf{2 . 0 9 5 4}$ & 0.48 & $\mathbf{2 . 5 8 0 9}$ & 2.38 & $\mathbf{- 4 . 6 2 5 7}$ & -0.42 & $\mathbf{- 2 . 6 1 2 6}$ & -2.11 \\
WV & $\mathbf{1 5 . 3 6 4 5}$ & 3.50 & $\mathbf{3 . 7 2 3 4}$ & 3.43 & $\mathbf{2 7 . 7 1 0 3}$ & 2.52 & $\mathbf{- 4 . 0 1 6 1}$ & -3.23 \\
AZ & $\mathbf{7 . 1 9 3 5}$ & 1.38 & $\mathbf{6 . 5 1 7 2}$ & 5.08 & $\mathbf{7 . 9 0 4 5}$ & 0.61 & $\mathbf{0 . 9 5 5 7}$ & 0.65 \\
CO & $\mathbf{1 2 . 9 7 2 1}$ & 2.90 & $\mathbf{0 . 4 2 4 8}$ & 0.38 & $\mathbf{2 6 . 2 9 6 8}$ & 2.34 & $\mathbf{1 0 . 0 0 9 1}$ & 7.91 \\
ID & $\mathbf{7 . 6 4 6 5}$ & 1.67 & $\mathbf{6 . 7 9 1 3}$ & 6.01 & $\mathbf{8 . 7 7 1 7}$ & 0.76 & $\mathbf{4 . 0 9 7 8}$ & 3.16 \\
MT & $\mathbf{8 . 6 3 8 8}$ & 1.90 & $\mathbf{5 . 0 1 6 5}$ & 4.47 & $\mathbf{4 3 . 6 2 4 0}$ & 3.83 & $\mathbf{1 . 7 5 0 3}$ & 1.36 \\
NV & $\mathbf{5 . 3 6 5 9}$ & 0.99 & $\mathbf{7 . 1 9 1 0}$ & 5.40 & $\mathbf{2 0 . 7 1 2 2}$ & 1.53 & $\mathbf{0 . 7 6 9 4}$ & 0.50 \\
NM & $\mathbf{1 4 . 9 4 5 2}$ & 3.12 & $\mathbf{1 . 2 4 8 1}$ & 1.06 & $\mathbf{3 0 . 5 0 1 1}$ & 2.54 & $\mathbf{- 3 . 9 2 0 1}$ & -2.90 \\
UT & $\mathbf{1 0 . 3 3 3 8}$ & 2.17 & $\mathbf{2 . 0 3 7 4}$ & 1.74 & $\mathbf{1 2 . 6 5 6 2}$ & 1.06 & $\mathbf{4 . 3 1 5 8}$ & 3.21 \\
WY & $\mathbf{3 . 7 8 7 0}$ & 0.77 & $\mathbf{3 . 6 8 7 0}$ & 3.02 & $\mathbf{3 1 . 2 6 5 5}$ & 2.52 & $\mathbf{0 . 3 7 4 1}$ & 0.27 \\
CA & $\mathbf{- 3 . 0 9 0 2}$ & -0.70 & $\mathbf{0 . 4 0 0 1}$ & 0.37 & $\mathbf{9 . 7 5 1 8}$ & 0.89 & $\mathbf{1 0 . 5 5 8 0}$ & 8.49 \\
OR & $\mathbf{- 1 0 . 7 7 8}$ & -2.34 & $\mathbf{0 . 0 5 4 5}$ & 0.05 & $\mathbf{- 5 . 6 5 3 4}$ & -0.49 & $\mathbf{- 0 . 9 5 3 9}$ & -0.73 \\
WA & $\mathbf{- 6 . 6 7 1 2}$ & -1.47 & $\mathbf{3 . 7 6 1 7}$ & 3.35 & $\mathbf{1 0 . 1 6 2 0}$ & 0.89 & $\mathbf{5 . 5 5 9 1}$ & 4.32 \\
R-squared & $\mathbf{0 . 4 1 3 2}$ & & $\mathbf{0 . 4 8 3 0}$ & & $\mathbf{0 . 3 1 3 7}$ & & $\mathbf{0 . 6 1 4 0}$ & \\
R-bar-squared & $\mathbf{0 . 3 9 8 2}$ & & $\mathbf{0 . 4 6 9 9}$ & & $\mathbf{0 . 2 9 6 2}$ & & $\mathbf{0 . 6 0 4 1}$ & \\
\hline
\end{tabular}


Appendix Table 2

OLS Regression Results for Public Works Programs

\begin{tabular}{|c|c|c|c|c|c|c|c|c|c|c|}
\hline & \multicolumn{2}{|c|}{$\begin{array}{l}\text { PWA Federal } \\
\text { Grants }\end{array}$} & \multicolumn{2}{|c|}{$\begin{array}{l}\text { PWA Non- } \\
\text { Federal } \\
\text { Grants }\end{array}$} & \multicolumn{2}{|c|}{$\begin{array}{l}\text { PWA Non- } \\
\text { Federal Loans }\end{array}$} & \multicolumn{2}{|c|}{ PRA Grants } & \multicolumn{2}{|c|}{ PBA Grants } \\
\hline & & t-stat. & & $\begin{array}{l}\text { t- } \\
\text { stat. }\end{array}$ & Coeff. & $\begin{array}{l}\text { t- } \\
\text { stat. }\end{array}$ & Coeff. & t-stat. & Coeff. & t-stat. \\
\hline $\begin{array}{l}\text { Intercept } \\
\text { Inverse }\end{array}$ & -90.5670 & -2.72 & 4.4346 & 0.52 & -15.0645 & -1.03 & -10.6473 & -0.86 & -0.4296 & -0.45 \\
\hline Population & -0.9121 & -6.19 & -0.0046 & -0.12 & -0.0337 & -0.52 & 1.0099 & 18.35 & -0.0131 & -3.08 \\
\hline $\begin{array}{l}\text { Square miles per } \\
\text { capita }\end{array}$ & 66.6841 & 7.62 & -0.8623 & -0.38 & 1.7895 & 0.47 & 65.4926 & 20.05 & 0.2259 & 0.89 \\
\hline$\%$ Urban & 0.0284 & 0.27 & 0.0303 & 1.12 & 0.0152 & 0.33 & -0.0384 & -0.98 & -0.0003 & -0.09 \\
\hline $\begin{array}{l}\text { \% Land on Farms } \\
\text { Tax returns per }\end{array}$ & -0.0353 & -0.42 & -0.0013 & -0.06 & -0.0326 & -0.89 & -0.0281 & -0.90 & -0.0093 & -3.86 \\
\hline $\begin{array}{l}\text { capita } \\
\text { Retail Sales per }\end{array}$ & -3.8093 & -1.67 & -0.3926 & -0.67 & -1.4086 & -1.40 & -0.4993 & -0.59 & 0.0125 & 0.19 \\
\hline capita, 1929 & 0.0132 & 1.08 & 0.0133 & 4.24 & 0.0131 & 2.44 & 0.0124 & 2.73 & 0.0020 & 5.52 \\
\hline$\%$ Black & 0.3347 & 2.12 & -0.0584 & -1.44 & -0.1905 & -2.74 & 0.1399 & 2.37 & -0.0099 & -2.17 \\
\hline $\begin{array}{l}\text { \% Illiterate } \\
\text { Growth retail } \\
\text { sales per cap., } \\
\text { 1929-33 }\end{array}$ & -0.3654 & -0.84 & 0.1543 & 1.38 & 0.4230 & 2.21 & 0.1598 & 0.98 & 0.0092 & 0.73 \\
\hline $\begin{array}{l}\text { 1929-33 } \\
\text { Unemployment }\end{array}$ & 17.4998 & 2.31 & 2.0085 & 1.03 & -3.3792 & -1.02 & 6.8904 & 2.44 & 0.6946 & 3.18 \\
\hline $\begin{array}{l}\text { rate } \\
\% \text { Farm failures }\end{array}$ & $\begin{array}{r}2.0795 \\
-0.3252\end{array}$ & $\begin{array}{r}2.20 \\
-0.81\end{array}$ & $\begin{array}{l}-0.3795 \\
-0.0287\end{array}$ & $\begin{array}{l}-1.56 \\
-0.28\end{array}$ & & $\begin{array}{l}-0.50 \\
-0.98\end{array}$ & $\begin{array}{l}-0.2390 \\
-0.4798\end{array}$ & $\begin{array}{l}-0.68 \\
-3.19\end{array}$ & $\begin{array}{r}-0.0512 \\
0.0093\end{array}$ & $\begin{array}{r}-1.88 \\
0.80\end{array}$ \\
\hline $\begin{array}{l}\text { Average farm Size } \\
\text { Mean Demo. \% } \\
\text { for Pres, 1896- } \\
1928\end{array}$ & -0.0382 & -1.39 & -0.0173 & -2.45 & -0.0126 & -1.05 & -0.0572 & -5.57 & -0.0006 & -0.70 \\
\hline $\begin{array}{l}\text { Roosevelt Swing } \\
\text { Std. Dev. Demo. } \\
\text { \% for Pres. 1896- }\end{array}$ & 0.4439 & 1.61 & -0.1349 & -1.91 & -0.0675 & -0.56 & 0.2680 & 2.61 & 0.0000 & 0.00 \\
\hline $\begin{array}{l}1932 \\
\text { Pres. Votes } \\
\text { 1932/population }\end{array}$ & 1.7989 & 3.05 & 0.2036 & 1.34 & 0.0524 & 0.20 & -0.3891 & -1.77 & -0.0087 & -0.51 \\
\hline $\begin{array}{l}1930 \\
\text { Avg. Tenure in }\end{array}$ & 2.2289 & 6.71 & 0.1182 & 1.38 & 0.1054 & 0.72 & 0.5560 & 4.48 & 0.0033 & 0.34 \\
\hline $\begin{array}{l}\text { House } \\
\text { Congressional } \\
\text { Committees }\end{array}$ & 0.0031 & 0.11 & -0.0100 & -1.38 & -0.0152 & -1.23 & 0.0016 & 0.15 & -0.0004 & -0.53 \\
\hline Agriculture & 6.0724 & 0.98 & $\mathbf{- 0 . 4 3 3 7}$ & -0.27 & -1.8793 & -0.69 & 1.1597 & 0.50 & -0.1324 & -0.74 \\
\hline $\begin{array}{l}\text { Appropriations } \\
\text { Banking and }\end{array}$ & 0.7482 & 0.12 & 2.5267 & 1.54 & 6.8569 & 2.44 & -2.7494 & -1.15 & 0.1065 & 0.58 \\
\hline Currency & 1.5660 & 0.20 & 3.7736 & 1.88 & 4.5172 & 1.31 & -1.4044 & -0.48 & -0.1122 & -0.50 \\
\hline
\end{tabular}




\begin{tabular}{|c|c|c|c|c|c|c|c|c|c|c|}
\hline Exports & 5.9626 & 0.70 & -0.4468 & -0.20 & -0.4366 & -0.12 & -0.0128 & 0.00 & -0.0715 & -0.29 \\
\hline Flood Control & -3.9228 & -0.50 & -0.3611 & -0.18 & 1.4713 & 0.42 & -1.3246 & -0.45 & -0.1509 & -0.66 \\
\hline Irrigation Control & 3.0791 & 0.42 & -2.7322 & -1.46 & 0.0264 & 0.01 & -8.4374 & -3.10 & -0.2351 & -1.12 \\
\hline Labor & 2.8185 & 0.33 & 0.9910 & 0.45 & 0.6493 & 0.17 & -1.8257 & -0.58 & -0.0399 & -0.16 \\
\hline Public Buildings & 4.8151 & 0.56 & -1.5997 & -0.73 & -0.8184 & -0.22 & 3.4642 & 1.09 & 0.1167 & 0.47 \\
\hline Public Lands & -3.4761 & -0.49 & -0.9636 & -0.53 & -3.2813 & -1.06 & 7.4955 & 2.86 & 0.0229 & 0.11 \\
\hline $\begin{array}{l}\text { Rivers and } \\
\text { Harbors }\end{array}$ & -0.0761 & -0.01 & 0.0310 & 0.02 & -1.2165 & -0.39 & -0.0035 & 0.00 & -0.2096 & -1.03 \\
\hline Roads & 1.6573 & 0.23 & -0.4964 & -0.27 & 0.8899 & 0.28 & -3.5658 & -1.34 & -0.1328 & -0.64 \\
\hline Ways and Means & -2.3899 & -0.31 & -1.6625 & -0.83 & 0.3717 & 0.11 & 0.2221 & 0.08 & 0.4806 & 2.13 \\
\hline \multicolumn{11}{|l|}{ State Dummies } \\
\hline ME & 4.6051 & 0.13 & -15.766 & -1.80 & 1.2129 & 0.08 & 6.0623 & 0.48 & 0.3689 & 0.37 \\
\hline MA & 0.3617 & 0.01 & -12.348 & -1.37 & 0.1245 & 0.01 & -4.9920 & -0.38 & -0.4300 & -0.43 \\
\hline NH & -32.9910 & -0.88 & -8.6626 & -0.90 & 2.6397 & 0.16 & -1.9467 & -0.14 & 0.7641 & 0.71 \\
\hline RI & 10.9573 & 0.25 & 8.3592 & 0.73 & 5.5676 & 0.29 & 9.4557 & 0.57 & 0.0382 & 0.03 \\
\hline VT & -12.3589 & -0.36 & -3.8358 & -0.43 & 5.9399 & 0.39 & 4.5303 & 0.35 & 1.0884 & 1.08 \\
\hline DE & -34.5998 & -0.64 & -0.3723 & -0.03 & 5.8397 & 0.25 & 7.3278 & 0.36 & 2.1389 & 1.37 \\
\hline NJ & -19.2639 & -0.59 & -8.5585 & -1.03 & 6.8873 & 0.48 & -7.5083 & -0.62 & 0.2341 & 0.25 \\
\hline NY & -30.9292 & -1.00 & -6.2640 & -0.79 & 3.9670 & 0.29 & 8.7147 & 0.75 & 1.1504 & 1.29 \\
\hline PA & -0.1230 & 0.00 & -5.1549 & -0.68 & 5.4584 & 0.42 & 6.8054 & 0.62 & 0.6472 & 0.76 \\
\hline IL & -35.3619 & -1.15 & -6.9255 & -0.87 & 5.2303 & 0.39 & 2.1909 & 0.19 & 1.2782 & 1.43 \\
\hline IN & -37.3404 & -1.26 & -6.5546 & -0.86 & 3.1908 & 0.25 & -7.9712 & -0.72 & 0.9938 & 1.16 \\
\hline MI & -30.0970 & -1.03 & -6.1794 & -0.82 & 3.7356 & 0.29 & 5.9843 & 0.55 & 1.0527 & 1.24 \\
\hline OH & -35.0495 & -1.15 & -5.2631 & -0.67 & 5.5890 & 0.42 & -5.1630 & -0.45 & 0.9256 & 1.05 \\
\hline WI & -28.8080 & -0.96 & -5.1633 & -0.67 & 5.8367 & 0.44 & -0.7821 & -0.07 & 0.8407 & 0.97 \\
\hline IA & -26.8661 & -0.91 & -6.9747 & -0.92 & 4.5445 & 0.35 & 1.8505 & 0.17 & 0.9477 & 1.11 \\
\hline $\mathbf{K S}$ & -21.8094 & -0.74 & -7.5591 & -0.99 & 4.9534 & 0.38 & 9.1375 & 0.83 & 0.7651 & 0.90 \\
\hline MN & -36.7470 & -1.00 & 0.2640 & 0.03 & 6.2271 & 0.38 & 4.6987 & 0.34 & 0.7990 & 0.75 \\
\hline MO & -16.8863 & -0.48 & -12.837 & -1.41 & -7.8290 & -0.50 & 7.4919 & 0.57 & 0.6517 & 0.64 \\
\hline $\mathbf{N E}$ & -26.8770 & -0.90 & -1.1679 & -0.15 & 16.7475 & 1.27 & 1.9703 & 0.18 & 0.8767 & 1.01 \\
\hline NDK & -22.8605 & -0.70 & -3.1896 & -0.38 & 8.0879 & 0.56 & 16.2833 & 1.33 & 1.0419 & 1.10 \\
\hline SD & -18.3767 & -0.60 & -6.3733 & -0.81 & 10.4314 & 0.77 & 7.3907 & 0.64 & 1.1304 & 1.27 \\
\hline $\mathbf{V A}$ & 43.0782 & 1.33 & -5.1571 & -0.62 & 6.6429 & 0.47 & 6.2403 & 0.52 & 1.0548 & 1.13 \\
\hline $\mathbf{A L}$ & 31.2983 & 1.00 & -3.7090 & -0.46 & 10.0604 & 0.73 & 10.6479 & 0.92 & 0.9813 & 1.09 \\
\hline $\mathbf{A R}$ & 29.0853 & 0.95 & -3.6287 & -0.46 & 12.9986 & 0.97 & 7.3761 & 0.65 & 0.8602 & 0.97 \\
\hline FL & 6.5421 & 0.21 & -1.7974 & -0.23 & 17.2550 & 1.29 & -4.0232 & -0.35 & 0.5599 & 0.64 \\
\hline GA & 31.8355 & 1.05 & -4.1178 & -0.53 & 10.9230 & 0.82 & 3.0794 & 0.27 & 0.9357 & 1.07 \\
\hline LA & 31.7603 & 1.02 & -1.8067 & -0.23 & 5.5990 & 0.41 & 6.9149 & 0.59 & 0.6288 & 0.70 \\
\hline MS & 51.8874 & 1.65 & -5.4315 & -0.67 & 6.3544 & 0.46 & 10.4059 & 0.89 & 1.0775 & 1.19 \\
\hline NC & 9.6745 & 0.33 & -4.8497 & -0.64 & 9.0361 & 0.70 & 0.7594 & 0.07 & 1.1497 & 1.35 \\
\hline SC & 51.2485 & 1.58 & 0.3477 & 0.04 & 16.5805 & 1.16 & 7.4269 & 0.61 & 0.4837 & 0.52 \\
\hline $\mathbf{T X}$ & 12.1384 & 0.39 & -1.5998 & -0.20 & 17.6660 & 1.30 & 9.6155 & 0.84 & 0.8677 & 0.98 \\
\hline KY & -9.8599 & -0.30 & -12.239 & -1.42 & -5.0251 & -0.34 & -2.8578 & -0.23 & 0.5420 & 0.5 \\
\hline
\end{tabular}




\begin{tabular}{|c|c|c|c|c|c|c|c|c|c|c|}
\hline MD & 19.5112 & 0.61 & -1.0753 & -0.13 & 8.3023 & 0.59 & -5.0129 & -0.42 & 2.4482 & 2.64 \\
\hline OK & -10.1685 & -0.34 & -0.2063 & -0.03 & 15.8630 & 1.21 & 6.9812 & 0.63 & 0.8626 & 1.00 \\
\hline TN & 39.4553 & 1.32 & -4.9806 & -0.65 & 9.6551 & 0.74 & 3.1108 & 0.28 & 1.0807 & 1.25 \\
\hline WV & -17.5854 & -0.59 & -9.4866 & -1.23 & 5.3585 & 0.41 & -9.6816 & -0.87 & 0.8776 & 1.02 \\
\hline $\mathbf{A Z}$ & 275.4149 & 7.79 & -7.1117 & -0.78 & 5.0519 & 0.33 & 42.0813 & 3.19 & 0.1886 & 0.18 \\
\hline $\mathrm{CO}$ & -42.6053 & -1.40 & -8.1495 & -1.04 & 3.3421 & 0.25 & 16.9614 & 1.49 & 0.3867 & 0.44 \\
\hline ID & -47.0487 & -1.51 & -6.6069 & -0.82 & 6.7779 & 0.49 & -0.3550 & -0.03 & 1.1886 & 1.32 \\
\hline MT & -25.9795 & -0.84 & 7.5954 & 0.96 & 24.0003 & 1.77 & 26.1363 & 2.26 & 1.3238 & 1.48 \\
\hline NV & 46.4145 & 1.27 & 4.8942 & 0.52 & 4.3855 & 0.27 & 141.0288 & 10.30 & 1.3199 & 1.25 \\
\hline NM & -5.1964 & -0.16 & -0.7534 & -0.09 & 8.9626 & 0.63 & 33.5038 & 2.76 & 0.8024 & 0.85 \\
\hline UT & -32.7021 & -1.01 & 1.3658 & 0.16 & 10.2887 & 0.72 & 19.5715 & 1.62 & 0.3474 & 0.37 \\
\hline WY & -59.0923 & -1.76 & -4.2214 & -0.49 & 8.0795 & 0.55 & 41.6576 & 3.32 & 1.2519 & 1.29 \\
\hline $\mathbf{C A}$ & -15.3471 & -0.51 & -4.9913 & -0.65 & 5.4106 & 0.41 & 14.0747 & 1.26 & 0.2181 & 0.25 \\
\hline OR & -18.4752 & -0.59 & -1.1970 & -0.15 & 8.4506 & 0.61 & 2.2006 & 0.19 & 1.3085 & 1.45 \\
\hline WA & -16.3501 & -0.53 & 4.1316 & 0.52 & 5.4214 & 0.40 & 10.6247 & 0.92 & 0.9297 & 1.04 \\
\hline R-squared & 0.1316 & & 0.5710 & & 0.3050 & & 0.6113 & & 0.6790 & \\
\hline R-bar-squared & 0.1095 & & 0.3310 & & 0.5800 & & 0.6014 & & 0.4410 & \\
\hline
\end{tabular}


Appendix Table 3

OLS Regression Results for Farm Programs

\begin{tabular}{|c|c|c|c|c|c|c|c|c|c|c|}
\hline & \multicolumn{2}{|c|}{ AAA Grants } & \multicolumn{2}{|c|}{ FCA Loans } & \multicolumn{2}{|c|}{ FSA Grants } & \multicolumn{2}{|c|}{ FSA Loans } & \multicolumn{2}{|c|}{ REA Loans } \\
\hline & Coeff. & t-stat. & Coeff. & t-stat. & Coeff. & t-stat. & Coeff. & t-stat. & Coeff. & t-stat. \\
\hline $\begin{array}{l}\text { Intercept } \\
\text { Inverse }\end{array}$ & -13.7358 & -0.90 & -0.3825 & -0.04 & 5.3538 & 2.58 & 9.2977 & 3.03 & -5.3719 & -2.11 \\
\hline Population & 0.2707 & 3.99 & 0.1653 & 4.13 & 0.0064 & 0.70 & 0.0046 & 0.34 & -0.0121 & -1.07 \\
\hline $\begin{array}{l}\text { Square miles per } \\
\text { capita }\end{array}$ & -21.0818 & -5.24 & 7.2006 & 3.03 & -0.0039 & -0.01 & 0.2034 & 0.25 & -1.0891 & -1.62 \\
\hline$\%$ Urban & -0.3980 & -8.24 & -0.2452 & -8.60 & 0.0123 & 1.87 & -0.0181 & -1.87 & -0.0540 & -6.71 \\
\hline $\begin{array}{l}\text { \% Land on Farms } \\
\text { Tax returns per }\end{array}$ & -0.0757 & -1.98 & 0.0726 & 3.22 & -0.0137 & -2.64 & -0.0084 & -1.10 & 0.0276 & 4.33 \\
\hline capita & 1.7000 & 1.62 & 0.7055 & 1.14 & -0.4570 & -3.21 & -1.5597 & -7.41 & -0.0435 & -0.25 \\
\hline $\begin{array}{l}\text { Retail Sales per } \\
\text { capita, } 1929\end{array}$ & 0.0155 & 2.76 & 0.0045 & 1.36 & -0.0041 & -5.33 & -0.0025 & -2.19 & 0.0003 & 0.36 \\
\hline$\%$ Black & 0.0661 & 0.91 & -0.0340 & -0.79 & -0.0010 & -0.10 & 0.0264 & 1.81 & -0.0024 & -0.20 \\
\hline $\begin{array}{l}\% \text { Illiterate } \\
\text { Growth retail } \\
\text { sales per cap., }\end{array}$ & -0.2014 & -1.00 & -0.5493 & -4.64 & -0.0355 & -1.30 & -0.1614 & -4.01 & -0.0190 & -0.57 \\
\hline $\begin{array}{l}\text { 1929-33 } \\
\text { Unemployment }\end{array}$ & -10.7206 & -3.08 & -8.4344 & -4.11 & -2.2345 & -4.73 & -3.5266 & -5.05 & 1.7717 & 3.06 \\
\hline rate & -2.0329 & -4.68 & -1.0571 & -4.13 & -0.0756 & -1.28 & -0.3988 & -4.58 & -0.0099 & -0.14 \\
\hline$\%$ Farm failures & -0.5335 & -2.88 & -0.2206 & -2.02 & 0.0500 & 1.98 & 0.0729 & 1.96 & -0.0346 & -1.12 \\
\hline $\begin{array}{l}\text { Average farm Size } \\
\text { Mean Demo. \% } \\
\text { for Pres, 1896- }\end{array}$ & 0.6336 & 50.13 & 0.2176 & 29.18 & 0.0116 & 6.76 & 0.0281 & 11.07 & -0.0029 & -1.38 \\
\hline $\begin{array}{l}1928 \\
\text { Roosevelt Swing } \\
\text { Std. Dev. Demo. } \\
\text { \% for Pres. 1896- }\end{array}$ & $\begin{array}{l}0.2294 \\
0.6214\end{array}$ & $\begin{array}{l}2.81 \\
4.92\end{array}$ & $\begin{array}{r}-0.0051 \\
0.0661\end{array}$ & $\begin{array}{r}-0.11 \\
0.89\end{array}$ & $\begin{array}{l}0.0004 \\
0.0517\end{array}$ & $\begin{array}{l}0.03 \\
3.01\end{array}$ & $\begin{array}{l}0.0152 \\
0.0050\end{array}$ & $\begin{array}{l}0.93 \\
0.20\end{array}$ & $\begin{array}{l}0.0770 \\
0.0995\end{array}$ & $\begin{array}{l}5.66 \\
4.72\end{array}$ \\
\hline $\begin{array}{l}1932 \\
\text { Pres. Votes } \\
\text { 1932/population }\end{array}$ & -0.3139 & -1.16 & 0.5254 & 3.28 & 0.0649 & 1.76 & 0.0575 & 1.05 & -0.0525 & -1.16 \\
\hline $\begin{array}{l}1930 \\
\text { Avg. Tenure in }\end{array}$ & 0.1315 & 0.86 & 0.1645 & 1.82 & -0.0383 & -1.85 & 0.0329 & 1.07 & 0.1187 & 4.66 \\
\hline $\begin{array}{l}\text { House } \\
\text { Congressional } \\
\text { Committees }\end{array}$ & 0.0392 & 3.03 & 0.0087 & 1.14 & -0.0001 & -0.04 & -0.0060 & -2.29 & 0.0028 & 1.28 \\
\hline Agriculture & 20.3306 & 7.17 & 6.4896 & 3.88 & -0.4200 & -1.09 & -0.0096 & -0.02 & 1.2280 & 2.60 \\
\hline $\begin{array}{l}\text { Appropriations } \\
\text { Banking and }\end{array}$ & -9.9392 & -3.38 & -1.6625 & -0.96 & -0.2599 & -0.65 & -0.5457 & -0.92 & -0.9172 & -1.87 \\
\hline Currency & -0.9138 & -0.25 & 1.9820 & 0.93 & -0.2197 & -0.45 & 0.5993 & 0.83 & 0.6461 & 1.08 \\
\hline Exports & -2.8680 & -0.73 & 1.7876 & 0.77 & -0.0735 & -0.14 & -0.0606 & -0.08 & 0.3768 & 0.58 \\
\hline Flood Control & 2.7696 & 0.76 & -0.3325 & -0.16 & -0.2985 & -0.61 & -1.6012 & -2.20 & 0.0509 & 0.08 \\
\hline Irrigation Control & -7.5366 & -2.24 & -1.3248 & -0.67 & 0.8643 & 1.90 & 0.3980 & 0.59 & -0.0131 & -0.02 \\
\hline
\end{tabular}




\begin{tabular}{|c|c|c|c|c|c|c|c|c|c|c|}
\hline Labor & 31.0280 & 7.96 & 4.0449 & 1.76 & -0.3128 & -0.59 & 0.8296 & 1.06 & -0.6424 & -0.99 \\
\hline Public Buildings & 8.0341 & 2.05 & 1.4440 & 0.62 & 0.0870 & 0.16 & 0.9054 & 1.15 & -0.6488 & -0.99 \\
\hline Public Lands & 3.4877 & 1.08 & -1.2547 & -0.66 & 0.4855 & 1.11 & -0.5333 & -0.82 & 0.4966 & 0.92 \\
\hline \multicolumn{11}{|l|}{ Rivers and } \\
\hline Harbors & -2.3336 & -0.72 & -2.6514 & -1.38 & -0.2782 & -0.63 & 0.1111 & 0.17 & 0.1860 & 0.34 \\
\hline Roads & -0.1668 & -0.05 & 3.1469 & 1.63 & -0.2806 & -0.63 & -0.4089 & -0.62 & 0.0291 & 0.05 \\
\hline Ways and Means & 2.2013 & 0.61 & -0.3755 & -0.18 & 0.1345 & 0.28 & 0.7493 & 1.04 & 0.3755 & 0.6 \\
\hline \multicolumn{11}{|l|}{ State Dummies } \\
\hline ME & -18.5647 & -1.18 & -13.5307 & -1.46 & -1.5598 & -0.73 & -1.7811 & -0.57 & -1.3641 & -0.52 \\
\hline MA & -6.3404 & -0.39 & -3.4611 & -0.37 & 0.1032 & 0.05 & 1.2147 & 0.38 & 1.1334 & 0.42 \\
\hline NH & -22.5855 & -1.32 & -11.3027 & -1.12 & -0.2387 & -0.10 & -0.3387 & -0.10 & -1.9627 & -0.6 \\
\hline RI & 7.5111 & 0.37 & 2.8550 & 0.24 & -1.3278 & -0.48 & -0.4992 & -0.12 & 0.7399 & 0.22 \\
\hline VT & -32.9341 & -2.06 & -19.6199 & -2.08 & -1.5692 & -0.72 & -2.4033 & -0.75 & -1.6319 & -0.61 \\
\hline DE & -33.4715 & -1.35 & -20.3997 & -1.39 & -0.1343 & -0.04 & -5.4579 & -1.09 & 4.4841 & 1. \\
\hline $\mathbf{N J}$ & -14.9785 & -1.00 & -4.4538 & -0.51 & -0.3247 & -0.16 & -1.1059 & -0.37 & 0.1447 & 0.0 \\
\hline NY & $\mathbf{- 5 5 . 4 7 9 7}$ & -3.90 & -18.2843 & -2.18 & 0.4242 & 0.22 & -3.2061 & -1.12 & -0.5912 & -0.25 \\
\hline PA & -19.0678 & -1.41 & -13.7481 & -1.73 & -2.4087 & -1.32 & -4.6436 & -1.72 & 2.2206 & 0.9 \\
\hline IL & -58.0380 & -4.09 & -21.0055 & -2.51 & -2.1615 & -1.12 & -6.8141 & -2.39 & 2.5374 & 1.07 \\
\hline IN & -14.5450 & -1.07 & -12.7449 & -1.59 & -2.1953 & -1.19 & -5.7271 & -2.10 & 2.6264 & 1.1 \\
\hline MI & -23.2810 & -1.73 & -9.9551 & -1.25 & -2.8453 & -1.55 & -4.1023 & -1.51 & 4.2735 & 1.9 \\
\hline OH & -19.0853 & -1.36 & -15.0477 & -1.82 & -1.5980 & -0.84 & -5.3484 & -1.90 & 2.1804 & 0.93 \\
\hline WI & -36.5363 & -2.66 & -2.2721 & -0.28 & -1.2839 & -0.69 & -3.2345 & -1.17 & 3.1679 & 1.2 \\
\hline IA & -1.5422 & -0.11 & -9.8338 & -1.23 & -3.2498 & -1.77 & -5.5893 & -2.06 & 4.1456 & 1.8 \\
\hline $\mathbf{K S}$ & 17.2793 & 1.27 & -4.2028 & -0.52 & 1.8475 & 1.00 & -0.8471 & -0.31 & -0.4448 & -0.20 \\
\hline MN & -112.1009 & -6.60 & -15.1175 & -1.51 & -1.7206 & -0.75 & -3.2537 & -0.95 & 2.3272 & 0.82 \\
\hline MO & -30.2350 & -1.86 & -17.8704 & -1.86 & 0.6145 & 0.28 & -2.9463 & -0.90 & 0.5762 & 0.2 \\
\hline NE & -33.3224 & -2.42 & -10.7541 & -1.32 & 1.8089 & 0.97 & -0.3190 & -0.12 & 3.5221 & 1.5 \\
\hline NDK & -73.1425 & -4.85 & 39.2487 & 4.41 & 25.6946 & 12.54 & -1.0714 & -0.35 & -1.7920 & -0.71 \\
\hline SD & -50.7771 & -3.59 & 17.4094 & 2.09 & 28.1018 & 14.65 & 6.7433 & 2.38 & -3.3049 & -1.40 \\
\hline VA & -24.6360 & -1.65 & -12.5404 & -1.43 & -3.4328 & -1.70 & -5.6179 & -1.88 & 1.5122 & 0.6 \\
\hline $\mathbf{A L}$ & -8.4834 & -0.59 & -6.6644 & -0.79 & -5.2825 & -2.71 & -1.2245 & -0.43 & 0.4691 & 0.20 \\
\hline $\mathbf{A R}$ & -12.6502 & -0.90 & -8.2145 & -0.99 & -5.4105 & -2.83 & -0.7798 & -0.28 & 0.4737 & 0.2 \\
\hline FL & -18.4285 & -1.31 & -0.0596 & -0.01 & -4.5856 & -2.41 & -2.1489 & -0.76 & 1.2435 & 0.53 \\
\hline GA & -17.6524 & -1.27 & -2.4901 & -0.30 & -5.6144 & -2.97 & -3.1661 & -1.13 & 2.7257 & 1.1 \\
\hline LA & -2.7256 & -0.19 & 0.3426 & 0.04 & -4.8011 & -2.47 & 0.1205 & 0.04 & -0.1536 & -0.06 \\
\hline MS & -14.3888 & -0.99 & -3.6128 & -0.42 & -4.8653 & -2.48 & -2.0895 & -0.72 & 1.5842 & 0.6 \\
\hline NC & -7.1400 & -0.53 & -2.1829 & -0.27 & -4.2322 & -2.30 & -6.0583 & -2.23 & -0.7778 & -0.34 \\
\hline SC & -5.9435 & -0.40 & 15.1025 & 1.71 & -3.4777 & -1.71 & -1.7728 & -0.59 & -0.5000 & -0.20 \\
\hline $\mathbf{T X}$ & 2.8795 & 0.20 & 4.4105 & 0.53 & -4.4069 & -2.29 & -2.0411 & -0.72 & 1.0424 & 0.4 \\
\hline KY & -7.1825 & -0.47 & -15.4250 & -1.70 & -1.4875 & -0.71 & -7.5006 & -2.43 & -0.9176 & -0.36 \\
\hline MD & -27.3470 & -1.85 & -12.2973 & -1.41 & -2.2940 & -1.14 & -6.3290 & -2.14 & -2.2758 & -0.9 \\
\hline OK & -5.0639 & -0.37 & -17.8716 & -2.21 & -2.5609 & -1.37 & -1.1138 & -0.40 & -0.6865 & -0.3 \\
\hline TN & -11.6153 & -0.85 & -6.2708 & -0.77 & -4.6146 & -2.48 & -6.9970 & -2.54 & 2.7918 & 1.2 \\
\hline
\end{tabular}




\begin{tabular}{lrrrrrrrrrr} 
WV & $\mathbf{- 2 2 . 0 3 8 5}$ & -1.60 & $\mathbf{- 1 2 . 8 2 8 8}$ & -1.58 & $\mathbf{- 2 . 2 0 5 1}$ & -1.18 & $\mathbf{- 5 . 8 9 4 7}$ & -2.14 & $\mathbf{- 3 . 2 2 3 7}$ & -1.41 \\
AZ & $\mathbf{- 1 1 . 9 1 4 3}$ & -0.73 & $\mathbf{- 1 1 . 8 3 0 8}$ & -1.23 & $\mathbf{- 3 . 3 0 4 5}$ & -1.50 & $\mathbf{- 1 . 4 5 8 5}$ & -0.45 & $\mathbf{2 . 6 2 1 3}$ & 0.97 \\
CO & $\mathbf{- 5 1 . 7 8 1 3}$ & -3.70 & $\mathbf{- 2 0 . 3 9 3 7}$ & -2.47 & $\mathbf{- 1 . 3 2 7 3}$ & -0.70 & $\mathbf{7 . 5 3 2 1}$ & 2.68 & $\mathbf{2 . 7 1 3 3}$ & 1.16 \\
ID & $\mathbf{- 1 7 . 4 5 3 4}$ & -1.22 & $\mathbf{- 1 0 . 6 7 5 0}$ & -1.26 & $\mathbf{- 4 . 0 2 1 2}$ & -2.07 & $\mathbf{4 . 7 8 8 3}$ & 1.67 & $\mathbf{1 . 7 0 3 5}$ & 0.71 \\
MT & $\mathbf{- 5 1 . 6 6 2 5}$ & -3.63 & $\mathbf{- 1 3 . 2 8 3 5}$ & -1.58 & $\mathbf{4 . 8 0 3 9}$ & 2.49 & $\mathbf{6 . 7 8 6 4}$ & 2.38 & $\mathbf{1 . 2 0 7 5}$ & 0.51 \\
NV & $\mathbf{- 6 6 . 9 7 5 3}$ & -3.97 & $\mathbf{- 5 1 . 6 2 8 0}$ & -5.19 & $\mathbf{- 3 . 6 4 2 4}$ & -1.59 & $\mathbf{0 . 7 5 4 3}$ & 0.22 & $\mathbf{1 . 1 9 7 5}$ & 0.43 \\
NM & $\mathbf{- 1 . 9 6 6 6}$ & -0.13 & $\mathbf{3 . 3 4 0 0}$ & 0.38 & $\mathbf{- 4 . 1 9 4 6}$ & -2.06 & $\mathbf{1 . 2 6 6 1}$ & 0.42 & $\mathbf{- 0 . 9 8 9 1}$ & -0.40 \\
UT & $\mathbf{- 1 1 . 5 1 9 4}$ & -0.78 & $\mathbf{- 4 . 3 2 0 2}$ & -0.49 & $\mathbf{- 3 . 0 0 4 0}$ & -1.49 & $\mathbf{1 1 . 7 3 6 6}$ & 3.94 & $\mathbf{3 . 6 2 5 4}$ & 1.46 \\
WY & $\mathbf{- 8 5 . 7 2 6 7}$ & -5.54 & $\mathbf{1 . 1 0 1 7}$ & 0.12 & $\mathbf{2 . 1 9 9 5}$ & 1.05 & $\mathbf{2 9 . 6 6 7 9}$ & 9.56 & $\mathbf{3 . 9 2 4 9}$ & 1.52 \\
CA & $\mathbf{- 4 3 . 6 8 3 6}$ & -3.18 & $\mathbf{- 3 . 2 0 9 4}$ & -0.40 & $\mathbf{- 1 . 5 4 0 8}$ & -0.83 & $\mathbf{0 . 4 6 8 7}$ & 0.17 & $\mathbf{- 0 . 8 9 7 1}$ & -0.39 \\
OR & $\mathbf{- 4 8 . 3 9 4 5}$ & -3.36 & $\mathbf{- 2 4 . 3 3 6 9}$ & -2.86 & $\mathbf{- 3 . 6 4 7 1}$ & -1.86 & $\mathbf{- 2 . 4 0 0 8}$ & -0.83 & $\mathbf{0 . 4 7 4 8}$ & 0.20 \\
WA & $\mathbf{- 4 2 . 7 2 5 0}$ & -3.00 & $\mathbf{- 3 0 . 7 3 1 5}$ & -3.66 & $\mathbf{- 3 . 8 2 6 4}$ & -1.98 & $\mathbf{- 1 . 3 5 8 2}$ & -0.48 & $\mathbf{2 . 8 4 3 9}$ & 1.20 \\
R-squared & $\mathbf{0 . 7 4 6 6}$ & & $\mathbf{0 . 6 9 3 4}$ & & $\mathbf{0 . 6 8 3 1}$ & & $\mathbf{0 . 4 7 4 7}$ & & $\mathbf{0 . 1 9 2 3}$ & \\
R-bar-squared & $\mathbf{0 . 7 4 0 2}$ & & $\mathbf{0 . 6 8 5 6}$ & & $\mathbf{0 . 6 7 5 1}$ & & $\mathbf{0 . 4 6 1 3}$ & & $\mathbf{0 . 1 7 1 7}$ & \\
\hline
\end{tabular}


Appendix Table 4

OLS Regression Results for Loan and Housing Programs

\begin{tabular}{|c|c|c|c|c|c|c|c|c|c|c|}
\hline & \multicolumn{2}{|l|}{ RFC Loans } & \multicolumn{2}{|c|}{ HOLC Loans } & \multicolumn{2}{|c|}{$\begin{array}{l}\text { FHA Loans } \\
\text { Insured }\end{array}$} & \multicolumn{2}{|c|}{ USHA Loans } & \multicolumn{2}{|c|}{ USHA Grants } \\
\hline & Coeff. & t-stat. & Coeff. & t-stat. & Coeff. & t-stat. & Coeff. & t-stat. & Coeff. & stat. \\
\hline $\begin{array}{l}\text { Intercept } \\
\text { Inverse }\end{array}$ & -24.9665 & -1.81 & -4.4768 & -1.31 & -8.5017 & -1.38 & 0.2743 & 0.20 & -0.6112 & -1.37 \\
\hline Population & 0.0635 & 1.04 & -0.0061 & -0.40 & 0.0526 & 1.93 & 0.0053 & 0.87 & 0.0018 & 0.91 \\
\hline $\begin{array}{l}\text { Square miles per } \\
\text { capita }\end{array}$ & -7.7720 & -2.14 & -2.8769 & -3.20 & -6.6808 & -4.13 & 0.1850 & 0.52 & 0.0776 & 0.66 \\
\hline \% Urban & 0.1590 & 3.65 & 0.1722 & 15.94 & 0.1101 & 5.67 & 0.0358 & 8.31 & 0.0037 & 2.61 \\
\hline $\begin{array}{l}\% \text { Land on Farms } \\
\text { Tax returns per }\end{array}$ & -0.1081 & -3.14 & -0.0256 & -2.99 & -0.0243 & -1.58 & -0.0153 & -4.48 & -0.0014 & -1.25 \\
\hline capita & 2.0112 & 2.13 & 3.8808 & 16.55 & 3.7223 & 8.83 & 0.3485 & 3.73 & 0.1102 & 3.59 \\
\hline $\begin{array}{l}\text { Retail Sales per } \\
\text { capita, } 1929\end{array}$ & 0.0228 & 4.50 & 0.0043 & 3.43 & 0.0050 & 2.20 & 0.0011 & 2.18 & 0.0004 & 2.44 \\
\hline$\%$ Black & -0.0502 & -0.77 & -0.0190 & -1.17 & 0.0228 & 0.78 & 0.0005 & 0.08 & 0.0049 & 2.30 \\
\hline $\begin{array}{l}\text { \% Illiterate } \\
\text { Growth retail } \\
\text { sales per cap., } \\
1929-33\end{array}$ & 0.2932 & 1.62 & -0.0494 & -1.10 & -0.1287 & -1.60 & -0.0488 & -2.73 & -0.0116 & -1.98 \\
\hline $\begin{array}{l}\text { Unemployment } \\
\text { rate }\end{array}$ & -0.2326 & -0.59 & 0.1618 & 1.67 & -0.1035 & -0.59 & 0.0202 & 0.52 & -0.0014 & -0.11 \\
\hline$\%$ Farm failures & 0.0761 & 0.45 & -0.0472 & -1.14 & -0.0583 & -0.78 & 0.0169 & 1.02 & 0.0026 & 0.48 \\
\hline $\begin{array}{l}\text { Average farm Size } \\
\text { Mean Demo. \% } \\
\text { for Pres, 1896- }\end{array}$ & 0.0111 & 0.97 & 0.0029 & 1.02 & -0.0223 & -4.38 & -0.0006 & -0.55 & -0.0005 & -1.40 \\
\hline 1928 & -0.0358 & -0.49 & -0.0358 & -1.96 & -0.0405 & -1.23 & 0.0008 & 0.12 & -0.0001 & -0.05 \\
\hline $\begin{array}{l}\text { Roosevelt Swing } \\
\text { Std. Dev. Demo. } \\
\text { \% for Pres. 1896- }\end{array}$ & -0.0934 & -0.82 & -0.0235 & -0.83 & -0.0526 & -1.03 & 0.0039 & 0.34 & 0.0038 & 1.03 \\
\hline $\begin{array}{l}1932 \\
\text { Pres. Votes } \\
\text { 1932/population }\end{array}$ & 0.2884 & 1.18 & -0.0596 & -0.98 & 0.1168 & 1.07 & 0.0233 & 0.96 & 0.0040 & 0.50 \\
\hline $\begin{array}{l}1930 \\
\text { Avg. Tenure in }\end{array}$ & 0.1123 & 0.82 & -0.1017 & -2.98 & 0.0908 & 1.48 & -0.0253 & -1.86 & -0.0023 & -0.51 \\
\hline $\begin{array}{l}\text { House } \\
\text { Congressional } \\
\text { Committees }\end{array}$ & 0.0013 & 0.11 & -0.0020 & -0.71 & -0.0104 & -1.99 & 0.0001 & 0.08 & 0.0001 & 0.35 \\
\hline Agriculture & -0.3161 & -0.12 & 1.1259 & 1.78 & 0.8019 & 0.70 & 0.0036 & 0.01 & 0.0277 & 0.33 \\
\hline $\begin{array}{l}\text { Appropriations } \\
\text { Banking and }\end{array}$ & 5.0264 & 1.90 & 0.5653 & 0.86 & -0.3006 & -0.25 & -0.1014 & -0.39 & 0.0799 & 0.93 \\
\hline Currency & 2.6330 & 0.81 & -1.5972 & -1.99 & -1.7824 & -1.23 & 0.1074 & 0.33 & 0.1318 & 1.25 \\
\hline Exports & -2.6420 & -0.75 & -0.7310 & -0.83 & -3.1821 & -2.02 & -0.5043 & -1.44 & -0.1148 & -1.00 \\
\hline Flood Control & -5.4848 & -1.68 & 1.8072 & 2.23 & 3.7556 & 2.58 & 0.0803 & 0.25 & 0.1991 & 1.87 \\
\hline
\end{tabular}




\begin{tabular}{|c|c|c|c|c|c|c|c|c|c|c|}
\hline Irrigation Control & -4.4054 & -1.46 & -0.4445 & -0.59 & -0.5737 & -0.43 & 0.1061 & 0.35 & 0.0463 & 0.47 \\
\hline Labor & 4.7455 & 1.35 & -0.6395 & -0.73 & -1.2436 & -0.79 & 1.1119 & 3.20 & 0.3448 & 3.02 \\
\hline Public Buildings & -1.1071 & -0.31 & -2.0852 & -2.38 & -0.7025 & -0.45 & 0.4002 & 1.14 & 0.0878 & 0.76 \\
\hline $\begin{array}{l}\text { Public Lands } \\
\text { Rivers and }\end{array}$ & -6.0680 & -2.08 & 1.4134 & 1.96 & -2.4608 & -1.90 & 0.1235 & 0.43 & 0.0234 & 0.25 \\
\hline Harbors & 0.6666 & 0.23 & 0.3557 & 0.49 & -0.4864 & -0.37 & 0.0608 & 0.21 & 0.2346 & 2.46 \\
\hline Roads & 11.3827 & 3.85 & 1.4259 & 1.94 & 1.1633 & 0.88 & -0.2710 & -0.93 & -0.0002 & 0.00 \\
\hline Ways and Means & 0.1363 & 0.04 & -1.2339 & -1.54 & -0.3369 & -0.23 & 0.0809 & 0.25 & 0.2377 & 2.26 \\
\hline \multicolumn{11}{|l|}{ State Dummies } \\
\hline ME & 46.6492 & 3.29 & 3.4153 & 0.97 & 1.9139 & 0.30 & -1.5669 & -1.12 & 0.0699 & 0.15 \\
\hline MA & -9.5206 & -0.66 & -3.6886 & -1.03 & -6.8312 & -1.06 & -0.7678 & -0.54 & 0.0178 & 0.04 \\
\hline NH & 5.3194 & 0.34 & -5.5638 & -1.45 & -0.2733 & -0.04 & -2.3670 & -1.55 & -0.1861 & -0.37 \\
\hline RI & -7.2312 & -0.39 & 8.3303 & 1.83 & 6.2033 & 0.76 & -3.4667 & -1.91 & -0.2150 & -0.36 \\
\hline VT & 65.4724 & 4.54 & 5.4113 & 1.52 & 7.8467 & 1.22 & -0.1891 & -0.13 & 0.1098 & 0.23 \\
\hline DE & 9.7187 & 0.43 & 10.0632 & 1.81 & 13.8298 & 1.38 & -0.7569 & -0.34 & 0.0696 & 0.10 \\
\hline NJ & 29.2933 & 2.18 & 14.0724 & 4.22 & 23.0547 & 3.84 & 0.3336 & 0.25 & 0.7593 & 1.74 \\
\hline NY & 16.2290 & 1.27 & 5.1669 & 1.63 & 7.7636 & 1.36 & -2.3577 & -1.86 & -0.1303 & -0.31 \\
\hline PA & 24.1905 & 1.99 & 1.8803 & 0.62 & 5.6039 & 1.03 & -0.7890 & -0.66 & 0.0840 & 0.21 \\
\hline IL & 18.3023 & 1.43 & 9.1740 & 2.89 & 10.2261 & 1.79 & -1.0900 & -0.86 & 0.0687 & 0.17 \\
\hline IN & 24.5439 & 2.00 & 16.7399 & 5.51 & 12.4240 & 2.27 & 0.5113 & 0.42 & 0.4291 & 1.08 \\
\hline MI & 27.0302 & 2.22 & 10.2926 & 3.41 & 9.1638 & 1.69 & -1.0425 & -0.87 & 0.1037 & 0.26 \\
\hline $\mathbf{O H}$ & 25.6486 & 2.03 & 17.1197 & 5.46 & 11.6092 & 2.06 & 0.2756 & 0.22 & 0.3561 & 0.87 \\
\hline WI & 23.3371 & 1.88 & 13.3686 & 4.35 & 4.5127 & 0.82 & -1.1757 & -0.96 & -0.0061 & -0.02 \\
\hline IA & 28.6972 & 2.35 & 9.3547 & 3.09 & 6.5368 & 1.20 & -0.1010 & -0.08 & 0.2066 & 0.52 \\
\hline KS & 8.3547 & 0.68 & 11.0874 & 3.65 & 11.3420 & 2.07 & -0.5136 & -0.42 & 0.1094 & 0.27 \\
\hline $\mathbf{M N}$ & 25.1133 & 1.64 & 6.8248 & 1.80 & 2.6328 & 0.39 & -1.6330 & -1.08 & -0.7018 & -1.41 \\
\hline MO & 3.9852 & 0.27 & 10.5744 & 2.90 & 10.2982 & 1.57 & -0.4430 & -0.30 & -0.7523 & -1.58 \\
\hline $\mathbf{N E}$ & 17.8534 & 1.44 & 14.1383 & 4.59 & 8.8778 & 1.60 & 0.4764 & 0.39 & 0.3855 & 0.96 \\
\hline NDK & 24.1773 & 1.78 & 11.3928 & 3.38 & 18.1090 & 2.99 & 0.3770 & 0.28 & 0.2801 & 0.63 \\
\hline SD & 32.0263 & 2.51 & 14.0203 & 4.44 & 13.6620 & 2.41 & 0.2147 & 0.17 & 0.3353 & 0.81 \\
\hline $\mathbf{V A}$ & 24.4286 & 1.82 & 10.7943 & 3.24 & 21.8782 & 3.65 & 0.8464 & 0.64 & 0.3777 & 0.87 \\
\hline $\mathbf{A L}$ & 22.5867 & 1.75 & 12.3661 & 3.86 & 17.3538 & 3.01 & 1.0626 & 0.83 & 0.5484 & 1.31 \\
\hline AR & 33.9766 & 2.68 & 10.2084 & 3.24 & 14.8071 & 2.61 & -0.2654 & -0.21 & 0.2358 & 0.57 \\
\hline FL & 20.8133 & 1.65 & 11.2823 & 3.60 & 20.8316 & 3.70 & 0.7498 & 0.60 & 0.1855 & 0.45 \\
\hline GA & 27.6051 & 2.20 & 11.7613 & 3.78 & 15.6881 & 2.81 & 1.4859 & 1.20 & 0.3790 & 0.93 \\
\hline LA & 42.1708 & 3.26 & 10.8618 & 3.39 & 15.7408 & 2.73 & 0.7380 & 0.58 & 0.2522 & 0.60 \\
\hline MS & 33.4586 & 2.57 & 10.6937 & 3.31 & 18.9203 & 3.25 & 1.3231 & 1.03 & 0.2227 & 0.53 \\
\hline NC & 23.2627 & 1.90 & 12.5916 & 4.16 & 13.6294 & 2.50 & 1.2388 & 1.03 & 0.3824 & 0.96 \\
\hline SC & 27.8538 & 2.07 & 11.1794 & 3.35 & 17.9332 & 2.99 & 1.6342 & 1.23 & 0.8346 & 1.91 \\
\hline $\mathbf{T X}$ & 24.2703 & 1.90 & 8.3144 & 2.63 & 18.1602 & 3.19 & 0.3334 & 0.26 & 0.2800 & 0.67 \\
\hline KY & 8.9130 & 0.64 & 10.6759 & 3.11 & 11.3826 & 1.84 & 2.1669 & 1.58 & 0.3570 & 0.79 \\
\hline MD & 38.4909 & 2.89 & 14.4764 & 4.38 & 23.0059 & 3.87 & 1.5322 & 1.16 & 0.1220 & 0.28 \\
\hline OK & 14.4946 & 1.17 & 14.8974 & 4.85 & 13.7389 & 2.49 & -0.1559 & -0.13 & 0.4913 & 1.22 \\
\hline
\end{tabular}




\begin{tabular}{|c|c|c|c|c|c|c|c|c|c|c|}
\hline $\mathbf{T N}$ & 35.1262 & 2.84 & 9.7461 & 3.18 & 15.2025 & 2.76 & 1.3435 & 1.10 & 0.8682 & 2.16 \\
\hline WV & 26.2991 & 2.12 & 12.2785 & 4.00 & 8.1009 & 1.47 & 1.4508 & 1.18 & 0.3628 & 0.90 \\
\hline $\mathbf{A Z}$ & 4.7638 & 0.32 & 12.4180 & 3.42 & 24.8876 & 3.81 & -1.9103 & -1.32 & -0.0099 & -0.02 \\
\hline $\mathrm{CO}$ & 18.2915 & 1.45 & 9.5128 & 3.04 & 9.0020 & 1.60 & -0.6653 & -0.53 & 0.1378 & 0.34 \\
\hline ID & 24.9472 & 1.93 & 12.1080 & 3.78 & 15.9237 & 2.77 & -1.3156 & -1.03 & 0.0856 & 0.20 \\
\hline MT & 29.7904 & 2.32 & 6.7979 & 2.14 & 14.3526 & 2.51 & -0.2668 & -0.21 & 0.1194 & 0.29 \\
\hline NV & 71.0754 & 4.67 & 7.3473 & 1.95 & 30.3546 & 4.48 & -3.2084 & -2.13 & -0.5071 & -1.03 \\
\hline NM & 34.3300 & 2.54 & 9.2016 & 2.75 & 21.0328 & 3.49 & -0.3273 & -0.25 & 0.2992 & 0.68 \\
\hline UT & 18.6770 & 1.39 & 20.4736 & 6.16 & 15.9506 & 2.67 & -1.1767 & -0.89 & 0.2057 & 0.47 \\
\hline WY & 9.4666 & 0.68 & 13.5953 & 3.93 & 29.9867 & 4.82 & -2.5657 & -1.86 & -0.3815 & -0.84 \\
\hline CA & 51.1405 & 4.12 & -2.5918 & -0.84 & 47.7099 & 8.63 & -2.0575 & -1.68 & -0.3463 & -0.86 \\
\hline OR & 28.9480 & 2.23 & 2.4506 & 0.76 & 16.9384 & 2.92 & -1.4424 & -1.12 & 0.0239 & 0.06 \\
\hline WA & 17.9019 & 1.40 & 1.2841 & 0.40 & 16.7896 & 2.93 & -1.9774 & -1.56 & -0.2072 & -0.50 \\
\hline R-squared & 0.1713 & & 0.5874 & & 0.3771 & & 0.1910 & & $\mathbf{0 . 8 8 3 0}$ & \\
\hline R-bar-squared & 0.1502 & & 0.5769 & & 0.3612 & & 0.1704 & & 0.6500 & \\
\hline
\end{tabular}


Appendix Table 5

OLS Regression Results for Aggregate Programs

\begin{tabular}{|c|c|c|c|c|c|c|c|c|}
\hline & \multicolumn{2}{|c|}{ Total Grants } & \multicolumn{2}{|c|}{$\begin{array}{l}\text { Total Relief } \\
\text { Grants }\end{array}$} & \multicolumn{2}{|c|}{$\begin{array}{l}\text { Total Public } \\
\text { Works Grants }\end{array}$} & \multicolumn{2}{|c|}{ Total Loans } \\
\hline & Coeff. & t-stat. & Coeff. & t-stat. & Coeff. & t-stat. & Coeff. & t-stat. \\
\hline $\begin{array}{l}\text { Intercept } \\
\text { Inverse }\end{array}$ & -26.0720 & -0.59 & 67.6995 & 4.44 & -97.2093 & -2.54 & -40.0274 & -1.71 \\
\hline Population & 0.3982 & 2.02 & 0.0242 & 0.36 & 0.0801 & 0.47 & 0.1877 & 1.81 \\
\hline $\begin{array}{l}\text { Square miles per } \\
\text { capita }\end{array}$ & 97.8550 & 8.35 & -5.8692 & -1.46 & 131.5403 & 13.05 & -2.3770 & -0.39 \\
\hline$\%$ Urban & -0.0293 & -0.21 & 0.2814 & 5.85 & 0.0200 & 0.17 & 0.0651 & 0.88 \\
\hline $\begin{array}{l}\text { \% Land on Farms } \\
\text { Tax returns per }\end{array}$ & -0.6467 & -5.81 & -0.5240 & -13.77 & -0.0738 & -0.77 & $\mathbf{- 0 . 0 8 9 7}$ & -1.53 \\
\hline capita & -6.4079 & -2.10 & -2.6932 & -2.58 & -4.6887 & -1.78 & 3.9072 & 2.43 \\
\hline $\begin{array}{l}\text { Retail Sales per } \\
\text { capita, } 1929\end{array}$ & 0.0332 & 2.03 & -0.0192 & -3.44 & 0.0409 & 2.91 & 0.0436 & 5.07 \\
\hline$\%$ Black & 0.2651 & 1.25 & -0.1523 & -2.10 & 0.4063 & 2.23 & -0.2653 & -2.38 \\
\hline $\begin{array}{l}\text { \% Illiterate } \\
\text { Growth retail } \\
\text { sales per cap., }\end{array}$ & -0.7407 & -1.27 & -0.4768 & -2.39 & -0.0422 & -0.08 & -0.1132 & -0.37 \\
\hline $\begin{array}{l}1929-33 \\
\text { Unemployment } \\
\text { rate }\end{array}$ & 3.1342 & 2.48 & 4.0304 & 9.32 & 1.4099 & 1.30 & -1.6877 & -2.54 \\
\hline$\%$ Farm failures & -0.9820 & -1.82 & 0.2274 & 1.23 & -0.8245 & -1.77 & -0.3005 & -1.06 \\
\hline $\begin{array}{l}\text { Average farm Size } \\
\text { Mean Demo. \% } \\
\text { for Pres, 1896- } \\
1928\end{array}$ & 0.5520 & 14.99 & 0.0148 & 1.17 & -0.1133 & -3.58 & 0.2433 & 12.57 \\
\hline $\begin{array}{l}\text { Roosevelt Swing } \\
\text { Std. Dev. Demo. } \\
\text { \% for Pres. 1896- }\end{array}$ & 1.8031 & 4.90 & 0.5148 & 4.09 & 0.5771 & 1.82 & -0.0053 & -0.03 \\
\hline $\begin{array}{l}1932 \\
\text { Pres. Votes } \\
\text { 1932/population }\end{array}$ & 0.2069 & 0.26 & -0.9095 & -3.36 & 1.6046 & 2.36 & 0.8276 & 1.99 \\
\hline $\begin{array}{l}1930 \\
\text { Avg. Tenure in }\end{array}$ & 2.7561 & 6.19 & 0.1760 & 1.16 & 2.9064 & 7.60 & 0.4055 & 1.73 \\
\hline $\begin{array}{l}\text { House } \\
\text { Congressional } \\
\text { Committees }\end{array}$ & 0.0274 & 0.73 & 0.0000 & 0.00 & -0.0058 & -0.18 & -0.0105 & -0.53 \\
\hline Agriculture & 23.7676 & 2.88 & -1.5451 & -0.55 & 6.6660 & 0.94 & 6.6952 & 1.54 \\
\hline $\begin{array}{l}\text { Appropriations } \\
\text { Banking and }\end{array}$ & -11.7471 & -1.37 & -2.4007 & -0.82 & 0.6320 & 0.09 & 9.1898 & 2.04 \\
\hline Currency & -7.2145 & -0.69 & -9.9732 & -2.78 & 3.8230 & 0.42 & 8.8585 & 1.61 \\
\hline Exports & -0.3763 & -0.03 & -3.7002 & -0.95 & 5.4315 & 0.55 & -2.2083 & -0.37 \\
\hline
\end{tabular}




\begin{tabular}{|c|c|c|c|c|c|c|c|c|}
\hline Flood Control & -5.2001 & -0.49 & -2.1777 & -0.60 & -5.7594 & -0.63 & -4.1650 & -0.75 \\
\hline Irrigation Control & -20.8424 & -2.13 & -5.9996 & -1.79 & -8.3256 & -0.99 & -5.5611 & -1.08 \\
\hline Labor & 39.3860 & 3.47 & 7.2371 & 1.86 & 1.9439 & 0.20 & 10.0680 & 1.69 \\
\hline Public Buildings & 10.0966 & 0.88 & -3.9044 & -1.00 & 6.7963 & 0.69 & -1.6642 & -0.28 \\
\hline Public Lands & 7.2117 & 0.77 & 1.3322 & 0.41 & 3.0787 & 0.38 & -9.1307 & -1.85 \\
\hline \multicolumn{9}{|l|}{ Rivers and } \\
\hline Harbors & -1.1888 & -0.13 & 1.0016 & 0.31 & -0.2581 & -0.03 & -2.2874 & -0.46 \\
\hline Roads & 2.8006 & 0.29 & 7.3402 & 2.24 & -2.5377 & -0.31 & 16.1604 & 3.21 \\
\hline Ways and Means & 0.4273 & 0.04 & 1.8571 & 0.52 & -3.3497 & -0.37 & 0.4093 & 0.07 \\
\hline \multicolumn{9}{|l|}{ State Dummies } \\
\hline ME & -20.5707 & -0.45 & 0.2363 & 0.02 & -4.7296 & -0.12 & 32.3304 & 1.34 \\
\hline MA & 22.2427 & 0.48 & 43.4795 & 2.72 & -17.4087 & -0.43 & -15.4975 & -0.63 \\
\hline NH & -77.8722 & -1.56 & -16.277 & -0.95 & -42.8362 & -1.00 & -13.9653 & -0.53 \\
\hline RI & 16.7490 & 0.28 & -16.687 & -0.82 & 28.8104 & 0.57 & 7.3421 & 0.24 \\
\hline VT & -50.6839 & -1.09 & -5.9710 & -0.38 & -10.5760 & -0.26 & 52.3619 & 2.14 \\
\hline DE & -41.2803 & -0.57 & 15.4953 & 0.62 & -25.5054 & -0.41 & 2.5051 & 0.07 \\
\hline $\mathbf{N J}$ & -25.3494 & -0.58 & 19.2575 & 1.29 & -35.0967 & -0.94 & 44.3516 & 1.94 \\
\hline NY & -81.7167 & -1.97 & -0.8992 & -0.06 & -27.3280 & -0.77 & 0.2156 & 0.01 \\
\hline PA & 25.5150 & 0.65 & 45.8569 & 3.41 & 2.1748 & 0.06 & 13.8015 & 0.67 \\
\hline IL & -72.6048 & -1.76 & 22.8686 & 1.62 & -38.8183 & -1.09 & 6.0047 & 0.28 \\
\hline IN & -40.7139 & -1.03 & 22.4182 & 1.65 & -50.8725 & -1.49 & 28.7883 & 1.38 \\
\hline MI & -13.2196 & -0.34 & 39.5818 & 2.94 & -29.2394 & -0.87 & 29.3689 & 1.42 \\
\hline OH & -15.7292 & -0.39 & 45.2667 & 3.24 & -44.5500 & -1.27 & 29.5721 & 1.38 \\
\hline WI & -35.6180 & -0.89 & 34.7075 & 2.54 & -33.9127 & -0.99 & 38.1824 & 1.81 \\
\hline IA & -31.5192 & -0.80 & 3.3110 & 0.25 & -31.0426 & -0.92 & 30.5056 & 1.47 \\
\hline $\mathbf{K S}$ & 28.5344 & 0.72 & 28.5750 & 2.11 & -19.4660 & -0.57 & 17.7285 & 0.85 \\
\hline $\mathbf{M N}$ & -111.9644 & -2.26 & 29.2329 & 1.73 & -30.9852 & -0.73 & 19.7579 & 0.76 \\
\hline MO & -34.3703 & -0.72 & 14.1140 & 0.87 & -21.5792 & -0.53 & -14.9334 & -0.60 \\
\hline NE & -41.4022 & -1.03 & 16.0709 & 1.17 & -25.1979 & -0.73 & 40.9651 & 1.94 \\
\hline NDK & -6.4276 & -0.15 & 50.7846 & 3.38 & -8.7249 & -0.23 & 79.7698 & 3.45 \\
\hline SD & 45.7383 & 1.11 & 85.0076 & 6.04 & -16.2289 & -0.46 & 76.8703 & 3.55 \\
\hline VA & 12.3426 & 0.28 & 0.7322 & 0.05 & 45.2162 & 1.21 & 25.1659 & 1.10 \\
\hline $\mathbf{A L}$ & 19.7406 & 0.47 & 1.1845 & 0.08 & 39.2185 & 1.09 & 37.7223 & 1.72 \\
\hline $\mathbf{A R}$ & 12.8852 & 0.31 & 4.5980 & 0.33 & 33.6929 & 0.95 & 47.6301 & 2.21 \\
\hline FL & -4.6601 & -0.11 & 18.6769 & 1.34 & 1.2815 & 0.04 & 48.0349 & 2.24 \\
\hline GA & -5.8773 & -0.15 & -5.5293 & -0.40 & 31.7328 & 0.91 & 47.8728 & 2.25 \\
\hline LA & 20.0420 & 0.48 & -2.1732 & -0.15 & 37.4972 & 1.04 & 58.7408 & 2.68 \\
\hline MS & 35.2301 & 0.84 & 5.6770 & 0.39 & 57.9392 & 1.60 & 46.7574 & 2.11 \\
\hline NC & -15.3661 & -0.39 & -8.6911 & -0.64 & 6.7339 & 0.20 & 36.1903 & 1.74 \\
\hline SC & 68.0705 & 1.56 & 24.7524 & 1.66 & 59.5069 & 1.59 & 69.0236 & 3.01 \\
\hline TX & 26.0486 & 0.63 & 14.2945 & 1.01 & 21.0218 & 0.59 & $\mathbf{5 3 . 0 7 1 5}$ & 2.44 \\
\hline KY & -7.1586 & -0.16 & 21.5040 & 1.40 & -24.4144 & -0.63 & -7.7321 & -0.33 \\
\hline MD & -6.0444 & -0.14 & 9.3538 & 0.64 & 15.8712 & 0.43 & 41.0349 & 1.81 \\
\hline
\end{tabular}




\begin{tabular}{lrrrrrrrr} 
OK & $\mathbf{1 5 . 2 3 5 5}$ & 0.38 & $\mathbf{2 7 . 0 8 5 6}$ & 1.98 & $\mathbf{- 2 . 5 3 1 0}$ & -0.07 & $\mathbf{2 4 . 5 3 7 4}$ & 1.17 \\
TN & $\mathbf{1 3 . 8 8 4 9}$ & 0.35 & $\mathbf{- 2 . 5 6 2 1}$ & -0.19 & $\mathbf{3 8 . 6 6 6 3}$ & 1.13 & $\mathbf{4 4 . 6 8 5 4}$ & 2.13 \\
WV & $\mathbf{- 1 3 . 2 4 7 6}$ & -0.33 & $\mathbf{4 2 . 7 8 2 1}$ & 3.13 & $\mathbf{- 3 5 . 8 7 5 9}$ & -1.04 & $\mathbf{2 2 . 7 7 1 1}$ & 1.08 \\
AZ & $\mathbf{3 1 2 . 5 1 2 8}$ & 6.60 & $\mathbf{2 2 . 5 7 0 8}$ & 1.39 & $\mathbf{3 1 0 . 5 7 3 2}$ & 7.63 & $\mathbf{8 . 8 3 4 4}$ & 0.35 \\
CO & $\mathbf{- 4 0 . 7 8 2 1}$ & -1.00 & $\mathbf{4 9 . 7 0 2 7}$ & 3.56 & $\mathbf{- 3 3 . 4 0 6 8}$ & -0.95 & $\mathbf{1 9 . 5 8 2 2}$ & 0.91 \\
ID & $\mathbf{- 3 9 . 8 1 8 5}$ & -0.95 & $\mathbf{2 7 . 3 0 7 3}$ & 1.91 & $\mathbf{- 5 2 . 8 2 2 0}$ & -1.47 & $\mathbf{3 7 . 7 8 9 5}$ & 1.72 \\
MT & $\mathbf{1 8 . 3 1 8 7}$ & 0.44 & $\mathbf{5 9 . 0 2 9 6}$ & 4.17 & $\mathbf{9 . 0 7 6 0}$ & 0.25 & $\mathbf{5 4 . 3 3 4 3}$ & 2.49 \\
NV & $\mathbf{1 6 2 . 4 6 8 4}$ & 3.31 & $\mathbf{3 4 . 0 3 8 6}$ & 2.03 & $\mathbf{1 9 3 . 6 5 7 4}$ & 4.58 & $\mathbf{2 9 . 0 3 4 4}$ & 1.12 \\
NM & $\mathbf{6 4 . 5 6 2 8}$ & 1.48 & $\mathbf{4 2 . 7 7 4 3}$ & 2.87 & $\mathbf{2 8 . 3 5 6 3}$ & 0.76 & $\mathbf{5 4 . 9 8 6 2}$ & 2.40 \\
UT & $\mathbf{1 . 9 7 9 3}$ & 0.05 & $\mathbf{2 9 . 3 4 3 1}$ & 1.98 & $\mathbf{- 1 1 . 4 1 7 5}$ & -0.31 & $\mathbf{5 8 . 6 0 1 7}$ & 2.57 \\
WY & $\mathbf{- 6 4 . 3 4 8 9}$ & -1.43 & $\mathbf{3 9 . 1 1 3 6}$ & 2.54 & $\mathbf{- 2 0 . 4 0 4 2}$ & -0.53 & $\mathbf{6 2 . 5 9 1 6}$ & 2.64 \\
CA & $\mathbf{- 3 2 . 4 3 1 6}$ & -0.81 & $\mathbf{1 7 . 6 1 9 7}$ & 1.29 & $\mathbf{- 6 . 0 4 5 6}$ & -0.18 & $\mathbf{4 7 . 7 1 8 8}$ & 2.26 \\
OR & $\mathbf{- 8 2 . 4 7 7 9}$ & -1.96 & $\mathbf{- 1 7 . 3 3 1}$ & -1.21 & $\mathbf{- 1 6 . 1 6 3 1}$ & -0.45 & $\mathbf{1 1 . 3 8 6 4}$ & 0.52 \\
WA & $\mathbf{- 3 1 . 0 6 7 9}$ & -0.75 & $\mathbf{1 2 . 8 1 1 6}$ & 0.90 & $\mathbf{- 0 . 6 6 4 2}$ & -0.02 & $\mathbf{- 7 . 3 9 5 8}$ & -0.34 \\
R-squared & $\mathbf{0 . 4 4 0 5}$ & & $\mathbf{0 . 4 2 5 8}$ & & $\mathbf{0 . 3 0 1 0}$ & & $\mathbf{0 . 3 4 7 6}$ & \\
R-bar-squared & $\mathbf{0 . 4 2 6 2}$ & & $\mathbf{0 . 4 1 1 2}$ & & $\mathbf{0 . 2 8 3 2}$ & & $\mathbf{0 . 3 3 1 0}$ & \\
\hline
\end{tabular}


Appendix Table 6

Comparisons of Adjusted R-squareds from Regressions with Political Variables Only and Structural, Relief, Recovery, and Reform Variables Only for Each Program

\begin{tabular}{|c|c|c|c|}
\hline & $\begin{array}{l}\text { Political } \\
\text { variables } \\
\text { only }\end{array}$ & $\begin{array}{l}\text { Structural, } \\
\text { relief, } \\
\text { recovery, } \\
\text { and reform } \\
\text { variables } \\
\text { only }\end{array}$ & $\begin{array}{l}\text { All variables } \\
\text { and state } \\
\text { dummy } \\
\text { variables } \\
\text { included }\end{array}$ \\
\hline \multicolumn{4}{|l|}{ RELIEF: } \\
\hline FERA Grants & 0.117 & 0.200 & 0.398 \\
\hline CWA Grants & 0.146 & 0.232 & 0.470 \\
\hline WPA Grants & 0.106 & 0.201 & 0.296 \\
\hline SSA Pub. Asst. Grants & 0.327 & 0.258 & 0.604 \\
\hline \multicolumn{4}{|l|}{ PUBLIC WORKS: } \\
\hline Federal PWA Grants & 0.007 & 0.055 & 0.110 \\
\hline Nonfed. PWA Grants & 0.008 & 0.028 & 0.331 \\
\hline Nonfed PWA Loans & 0.003 & 0.005 & 0.580 \\
\hline PRA Grants & 0.151 & 0.555 & 0.601 \\
\hline PBA Grants & 0.007 & 0.040 & 0.441 \\
\hline \multicolumn{4}{|l|}{ FARM PROGRAMS: } \\
\hline AAA Grants & 0.175 & 0.665 & 0.740 \\
\hline FCA Loans & 0.284 & 0.613 & 0.686 \\
\hline FSA Grants & 0.272 & 0.282 & 0.675 \\
\hline FSA Loans & 0.145 & 0.301 & 0.461 \\
\hline REA Loans & 0.065 & 0.090 & 0.172 \\
\hline \multicolumn{4}{|l|}{ LOANS AND HOUSING: } \\
\hline RFC Loans & 0.019 & 0.105 & 0.150 \\
\hline HOLC Loans & 0.080 & 0.505 & 0.577 \\
\hline FHA Loans Insured & 0.034 & 0.259 & 0.361 \\
\hline USHA Loan Contracts & 0.019 & 0.137 & 0.170 \\
\hline USHA Grants & 0.004 & 0.047 & 0.650 \\
\hline \multicolumn{4}{|l|}{ AGGREGATES: } \\
\hline Total Grants & 0.206 & 0.367 & 0.426 \\
\hline Relief Grants & 0.151 & 0.268 & 0.411 \\
\hline Public Works Grants & 0.065 & 0.229 & 0.283 \\
\hline Total Loans & 0.175 & 0.290 & 0.331 \\
\hline
\end{tabular}

